Article

\title{
Elevated Ozone Concentration Reduces Photosynthetic Carbon Gain but Does Not Alter Leaf Structural Traits, Nutrient Composition or Biomass in Switchgrass
}

\author{
Shuai $\mathrm{Li}^{1,2}{ }^{10}$, Galatéa Courbet ${ }^{3}$, Alain Ourry ${ }^{3}\left(\mathbb{1}\right.$ and Elizabeth A. Ainsworth ${ }^{1,4, *}$ \\ 1 DOE Center for Advanced Bioenergy and Bioproducts Innovation and Carl R. Woese Institute for Genomic \\ Biology, University of Illinois at Urbana-Champaign, Urbana, IL 61801, USA; shuaili@illinois.edu \\ 2 Institute for Sustainability, Energy, and Environment, University of Illinois at Urbana-Champaign, Urbana, \\ IL 61801, USA \\ 3 Normandie Université, UNICAEN, INRA, UMR 950 Ecophysiologie Végétale, Agronomie et nutritions N, C, \\ S, Esplanade de la Paix, Université Caen Normandie, 14032 Caen Cedex 5, France; \\ galatea.courbet@unicaen.fr (G.C.); alain.ourry@unicaen.fr (A.O.) \\ 4 Global Change and Photosynthesis Research Unit, USDA ARS, Urbana, IL 61801, USA \\ * Correspondence: lisa.ainsworth@ars.usda.gov
}

Received: 27 February 2019; Accepted: 29 March 2019; Published: 2 April 2019

\begin{abstract}
Elevated tropospheric ozone concentration $\left(\mathrm{O}_{3}\right)$ increases oxidative stress in vegetation and threatens the stability of crop production. Current $\mathrm{O}_{3}$ pollution in the United States is estimated to decrease the yields of maize (Zea mays) up to $10 \%$, however, many bioenergy feedstocks including switchgrass (Panicum virgatum) have not been studied for response to $\mathrm{O}_{3}$ stress. Using Free Air Concentration Enrichment (FACE) technology, we investigated the impacts of elevated $\mathrm{O}_{3}\left(\sim 100 \mathrm{nmol} \mathrm{mol}^{-1}\right)$ on leaf photosynthetic traits and capacity, chlorophyll fluorescence, the Ball-Woodrow-Berry (BWB) relationship, respiration, leaf structure, biomass and nutrient composition of switchgrass. Elevated $\mathrm{O}_{3}$ concentration reduced net $\mathrm{CO}_{2}$ assimilation rate $(A)$, stomatal conductance $\left(g_{\mathrm{s}}\right)$, and maximum $\mathrm{CO}_{2}$ saturated photosynthetic capacity $\left(V_{\max }\right)$, but did not affect other functional and structural traits in switchgrass or the macro- (except potassium) and micronutrient content of leaves. These results suggest that switchgrass exhibits a greater $\mathrm{O}_{3}$ tolerance than maize, and provide important fundamental data for evaluating the yield stability of a bioenergy feedstock crop and for exploring $\mathrm{O}_{3}$ sensitivity among bioenergy feedstocks.
\end{abstract}

Keywords: ozone; switchgrass; photosynthesis; stomatal conductance; chlorophyll fluorescence; leaf anatomy; biomass

\section{Introduction}

Obtaining renewable energy from biomass feedstocks is projected to reduce reliance on traditional fossil fuels and emissions of greenhouse gases while benefitting economic growth and energy security [1-3]. Currently, the production of corn-based ethanol is the most common biofuel feedstock in the USA, but ethanol can also be derived from woody feedstocks or other dedicated bioenergy crops [1,3-5]. Switchgrass, a native perennial warm-season $C_{4}$ grass of North America [6], has been recognized as an emerging and promising bioenergy feedstock $[4,7,8]$. With broad adaptability, switchgrass can produce high biomass yields under limited water and nutrient supply on marginal croplands [9-11]. Switchgrass also has the potential to produce greater biomass yields (13 $\left.\mathrm{Mg} \mathrm{ha}^{-1}\right)$ than maize grain (11 $\left.\mathrm{Mg} \mathrm{ha}^{-1}\right)$ given similar inputs [4]. Several studies have examined the impact 
of environmental variables on switchgrass [10,12-15], the majority of those focusing on switchgrass breeding and management, biomass improvement and enhancement and conversion efficiency of biomass to biofuels $[1,3,7-11,16]$. Another important consideration is the yield stability of bioenergy feedstocks, which can be altered by atmospheric pollutants.

Tropospheric ozone $\left(\mathrm{O}_{3}\right)$ is a well-known airborne pollutant that forms from reactions of $\mathrm{NO}_{\mathrm{x}}$ with volatile organic compounds in the presence of sunlight $[17,18]$. The average current ambient $\mathrm{O}_{3}$ concentration in the northern hemisphere is $20-50 \mathrm{nmol} \mathrm{mol}^{-1}$, but, as a result of time-varying and non-uniform distribution of pollutant precursors, higher concentrations of $120 \mathrm{nmol} \mathrm{mol}^{-1}$ or more can be observed in industrial cities [19-23]. Long-range transport events may carry precursor pollutants over long distances outside of industrial areas, and even over distances of intercontinental and hemispheric scales [24-26]. Current concentration of tropospheric $\mathrm{O}_{3}$ significantly reduce photosynthesis and productivity on scales from individual plants to ecosystems, and lead to global crop yield losses and reduced terrestrial net primary productivity [23,27-34].

As a strong oxidant, $\mathrm{O}_{3}$ enters plants through the stomata and reacts with the plasmalemma to form reactive oxygen species (ROS) including hydrogen peroxide and superoxide, which can subsequently alter cellular components, trigger signaling cascades, and eventually cause cellular damage or even programmed cell death [23,35-39]. In addition, the photosynthetic apparatus can be damaged by $\mathrm{O}_{3}$ leading to reduced ribulose-1,5-bisphosphate carboxylase/oxygenase (Rubisco) activity in the chloroplast, lower rates of carbon fixation and reduced quantum yield of primary photochemistry [33,38-42]. $\mathrm{O}_{3}$ has also been shown to alter the relationship between photosynthesis and stomatal conductance and reduce water use efficiency [43]. However, $\mathrm{O}_{3}$ effects on stomatal conductance vary greatly across plant species and depend on levels of $\mathrm{O}_{3}$ exposure [44]. Previous studies have found that exposure to very high $\mathrm{O}_{3}$ can induce rapid stomata closure, subsequently limiting $\mathrm{CO}_{2}$ uptake and reducing net assimilation [39,45]. Additionally, previous studies have shown that exposure to chronic $\mathrm{O}_{3}$ pollution can induce stomatal sluggishness resulting in incomplete stomatal closure and reduced water use efficiency [46,47]. Changes in stomatal conductance at elevated $\mathrm{O}_{3}$ can result from damage to guard cells and/or from altered stomatal density on the leaf surface, but few studies have investigated such changes in $\mathrm{C}_{4}$ plants. The Ball-Woodrow-Berry (BWB) model [48] describes stomatal conductance as a linear function of the relationship between photosynthesis, atmospheric humidity and the concentration of $\mathrm{CO}_{2}$ at the leaf surface, and is fundamental to scaling from the leaf to the canopy or to model carbon and water flux [49]. Whether $\mathrm{O}_{3}$ pollution alters this relationship in switchgrass has not been investigated and is important for accurately modeling carbon and water fluxes in an elevated $\mathrm{O}_{3}$ environment.

It is well established that elevated $\mathrm{O}_{3}$ negatively impacts plant growth, development and production in $\mathrm{C}_{3}$ species, but fewer studies have been conducted to understand the overall effects of elevated $\mathrm{O}_{3}$ on $\mathrm{C}_{4}$ species. Previous studies have shown that elevated $\mathrm{O}_{3}$ significantly reduce photosynthesis and biomass in maize (Zea mays L.) [50-54] and sugarcane [55-57]. In particular, $\mathrm{O}_{3}$ caused yield loss are greater in dry and hot conditions than that in wet and optimal temperature conditions, implying that the yield response of $\mathrm{O}_{3}$ can be modulated by precipitation in future climate [31,53]. Due to possessing Kranz anatomy and phosphoenolpyruvate carboxylase (PEPC) but very low photorespiration, $\mathrm{C}_{4}$ plants generally exhibit high photosynthetic capacity under some environmental conditions, and thus $\mathrm{O}_{3}$ response of $\mathrm{C}_{3}$ and $\mathrm{C}_{4}$ species might be very different. Additionally, greater sensitivity to $\mathrm{O}_{3}$ has been associated with lower leaf mass per unit area in $\mathrm{C}_{3}$ species [58], but the effects of $\mathrm{O}_{3}$ on $\mathrm{C}_{4}$ species have been less well studied. Therefore, examining leaf photosynthetic and anatomical responses to $\mathrm{O}_{3}$ in $\mathrm{C}_{4}$ species can provide important insight into understanding the mechanisms of $\mathrm{O}_{3}$ response as well as exploring $\mathrm{O}_{3}$ sensitivity of potential bioenergy species.

In the present study, we used switchgrass, a promising bioenergy feedstock crop, to investigate the effects of season-long elevated $\mathrm{O}_{3}$ on leaf photosynthetic gas exchange, respiration, chlorophyll fluorescence, leaf structure, biomass and nutrient composition. Considering switchgrass has a close 
phyologenetic relationship with maize [59], we hypothesized that elevated $\mathrm{O}_{3}$ would lead to: (a) reductions in photosynthetic traits and capacity; (b) alterations in leaf structure; and (c) changes in biomass and nutrient composition.

\section{Results}

\subsection{Leaf Photosynthetic and Chlorophyll Fluorescence Responses to Elevated $\mathrm{O}_{3}$}

On 25 July (DOY 206) and 13 August (DOY 225), 2018, elevated $\mathrm{O}_{3}$ concentration significantly reduced in situ net $\mathrm{CO}_{2}$ assimilation rates $(A)$ and stomatal conductance to water vapor $\left(g_{\mathrm{s}}\right)$, but there was no significant effect of elevated $\mathrm{O}_{3}$ on intercellular $\mathrm{CO}_{2}$ concentration $\left(C_{\mathrm{i}}\right)$ or instantaneous water use efficiency (iWUE) (Figure 1). Chlorophyll fluorescence parameters were not as consistently altered by elevated $\mathrm{O}_{3}$. A significant reduction in PSII maximum efficiency $\left(F_{\mathrm{v}}{ }^{\prime} / F_{\mathrm{m}}{ }^{\prime}\right)$ was observed on DOY 206, but not DOY 225 (Figure 2a), while significant reductions in quantum yield of PSII ( $\left.\Phi_{\mathrm{PSII}}\right)$ and electron transport rate (ETR) were only observed on DOY 225 (Figure 2b,c). The coefficient of photochemical quenching $(q P)$ was not affected by elevated $\mathrm{O}_{3}$ on either DOY 206 or DOY 225 in 2018 (Figure 2d). A slight decrease in $g_{\mathrm{s}}$ in aging leaves (DOY 206 vs. DOY 225) was observed in both ambient $(0.24 \pm 0.020$ vs. $0.21 \pm 0.017)$ and elevated $(0.18 \pm 0.016$ vs. $0.16 \pm 0.015) \mathrm{O}_{3}$ (Figure $\left.1 b\right)$. Decreased $F_{\mathrm{v}}{ }^{\prime} / F_{\mathrm{m}}{ }^{\prime}, \Phi_{\mathrm{PSII}}$ and ETR and increased $q P$ in aging leaves were also observed in ambient and elevated $\mathrm{O}_{3}$ (Figure 2). Elevated $\mathrm{O}_{3}$ concentration did not affect the maximum carboxylation capacity of phosphoenolpyruvate $\left(V_{\text {pmax }}\right)$ (Figure $\left.3 a\right)$, but reduced the maximum $\mathrm{CO}_{2}$ saturated photosynthetic capacity $\left(V_{\max }\right)$ (Figure $\left.3 b\right)$ in switchgrass.
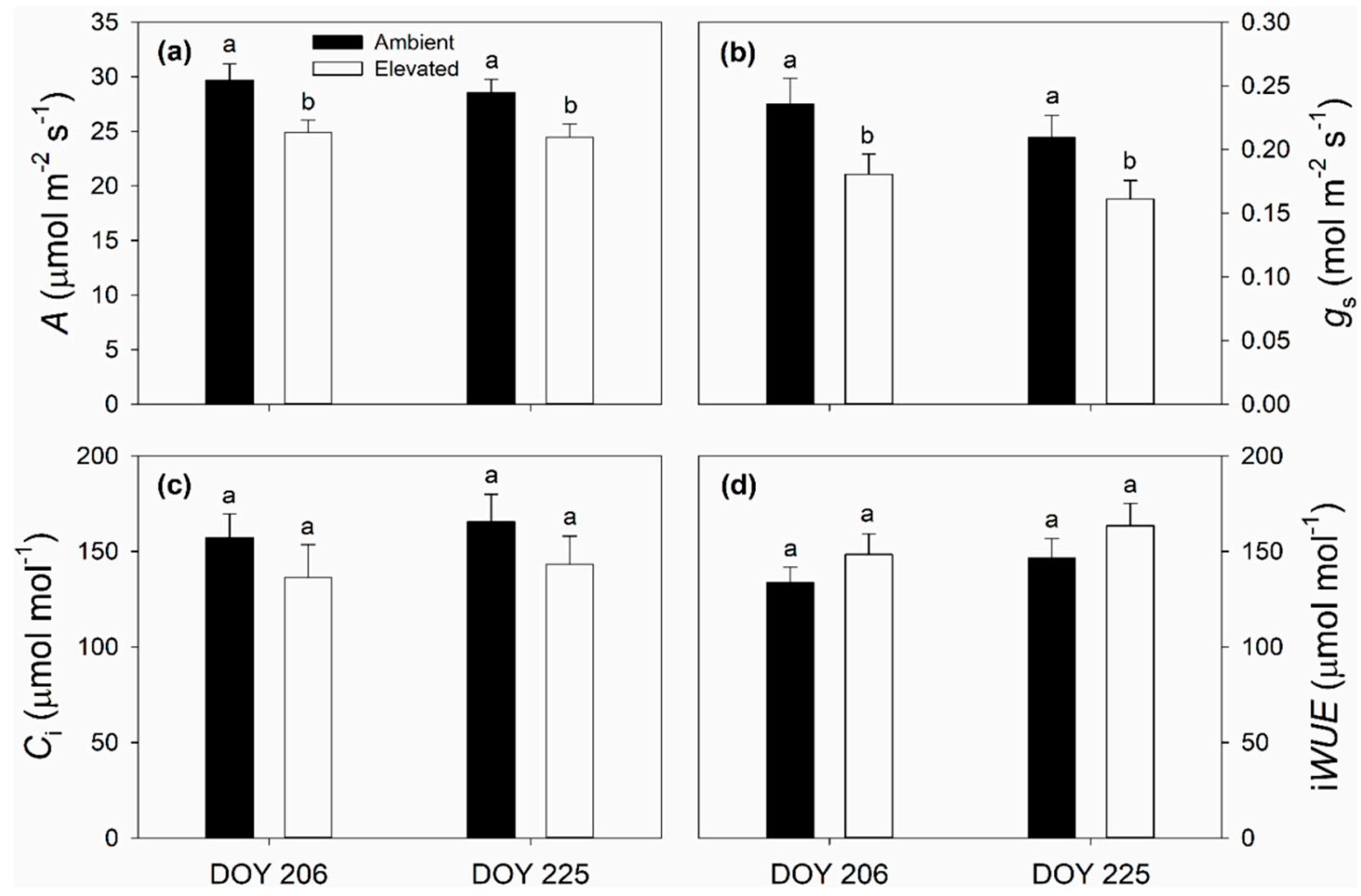

Figure 1. Average values of: net $\mathrm{CO}_{2}$ assimilation rate $(A)(\mathbf{a})$; stomatal conductance $\left(g_{\mathrm{s}}\right)(\mathbf{b})$; intercellular $\mathrm{CO}_{2}$ concentration $\left(C_{\mathrm{i}}\right)(\mathbf{c})$; and instantaneous water use efficiency (iWUE) (d) of ambient and elevated $\mathrm{O}_{3}$ concentration treated switchgrass leaf measured on 25 July (DOY 206) and 13 August (DOY 225) in 2018. Error bars show standard errors $(n=3)$. Significant differences between ambient and elevated $\mathrm{O}_{3}$ are indicated by different letters. 

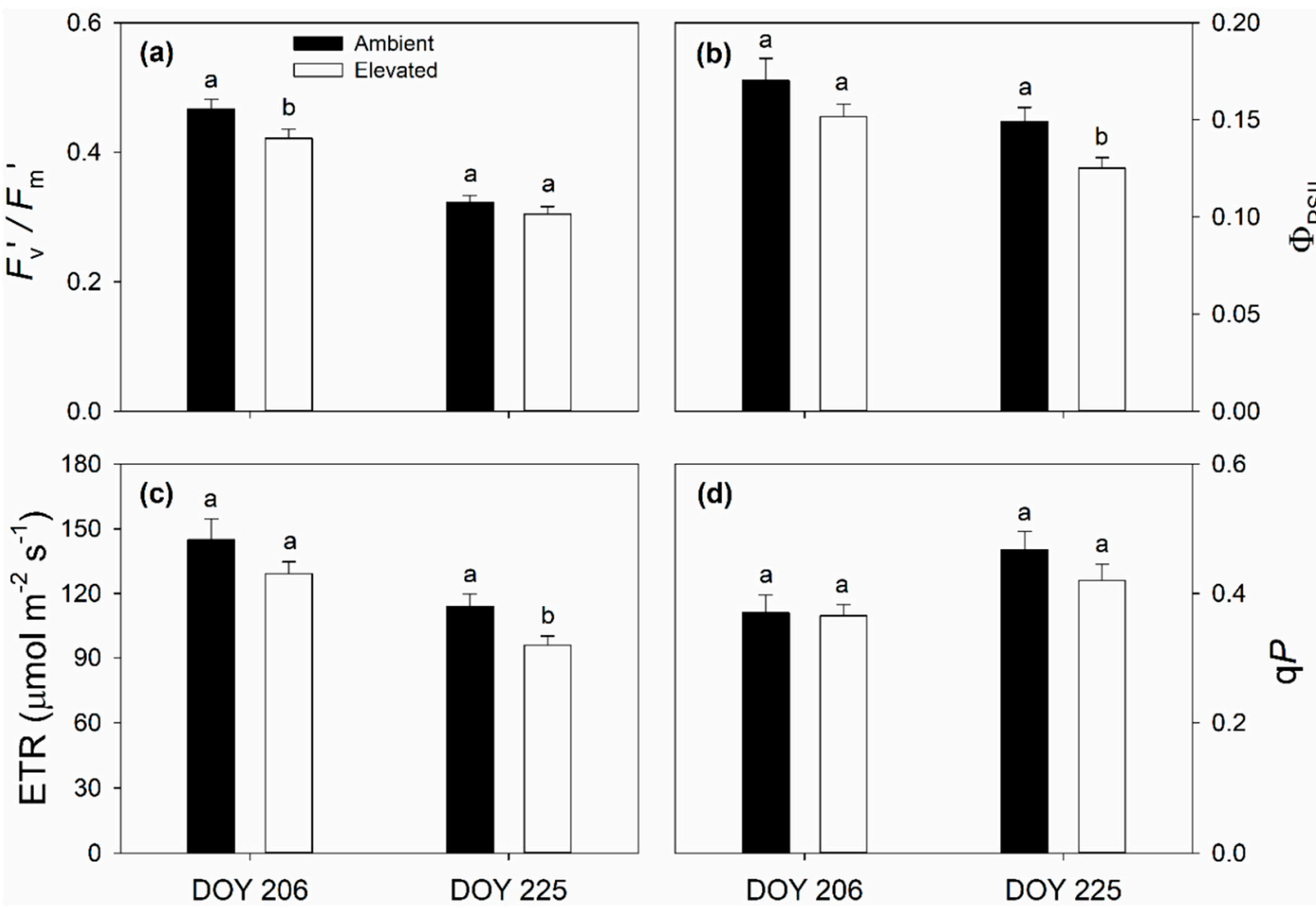

Figure 2. PSII maximum efficiency $\left(F_{\mathrm{v}^{\prime}} / F_{\mathrm{m}}{ }^{\prime}\right)(\mathbf{a})$; quantum yield of PSII (ФPSII) (b); electron transport rate (ETR) (c); and coefficient of photochemical quenching $(q P)\left(\right.$ d) in ambient and elevated $\mathrm{O}_{3}$ concentration treated switchgrass leaf measured on DOY 206 and DOY 225 in 2018. Error bars show standard errors $(n=3)$. Significant differences between ambient and elevated $\mathrm{O}_{3}$ are indicated by different letters.
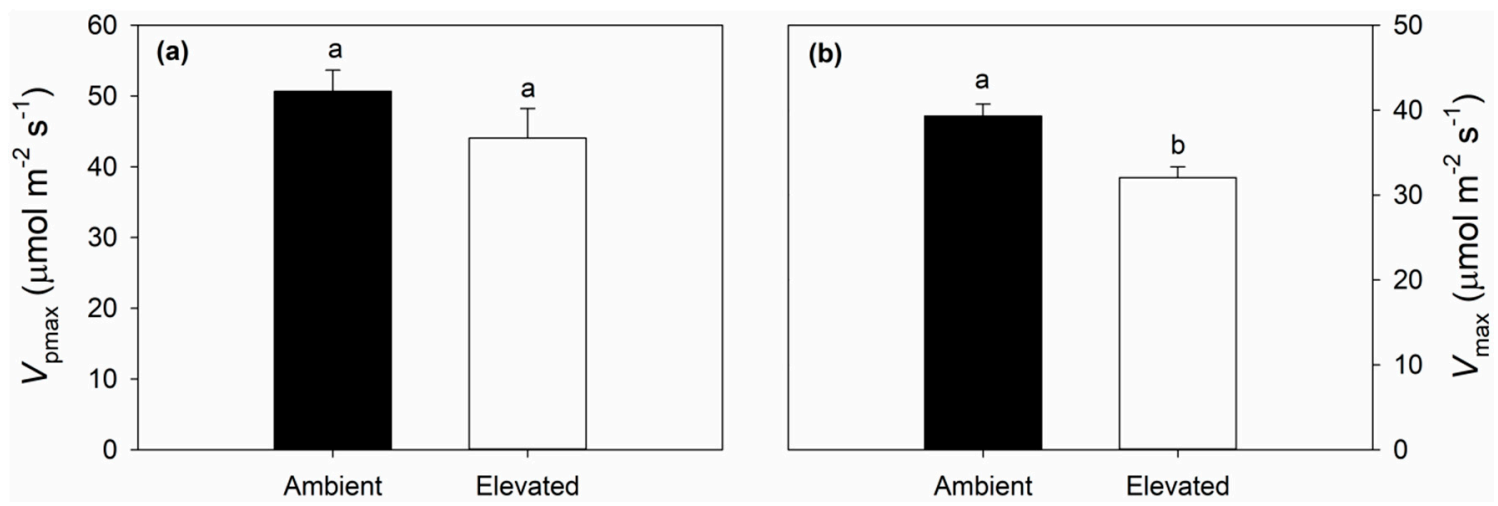

Figure 3. Maximum carboxylation capacity of PEPC $\left(V_{\text {pmax }}\right)(\mathbf{a})$; and $\mathrm{CO}_{2}$-saturated photosynthetic rate $\left(V_{\max }\right)(\mathbf{b})$ of switchgrass grown at ambient and elevated $\mathrm{O}_{3}$ concentrations measured on DOY 206 in 2018. Error bars show standard errors $(n=3)$. Significant differences between ambient and elevated $\mathrm{O}_{3}$ are indicated by different letters.

\subsection{Changes in the BWB Relationship due to Elevated $\mathrm{O}_{3}$}

To further estimate the effect of elevated $\mathrm{O}_{3}$ on switchgrass carbon and water fluxes, the Ball-Woodrow-Berry (BWB) model was applied to gas exchange data collected in the field. As predicted, $\frac{A H_{s}}{C_{s}}$ was strongly correlated with $g_{s}$ in both ambient $(p<0.0001)$ and elevated $(p<0.0001) \mathrm{O}_{3}$ (Figure 4 ). However, there was no significant difference in the slope or intercept of the relationship between $g_{\mathrm{s}}$ and $\frac{A H_{s}}{C_{s}}$ in ambient and elevated $\mathrm{O}_{3}$ (Figure 4). 


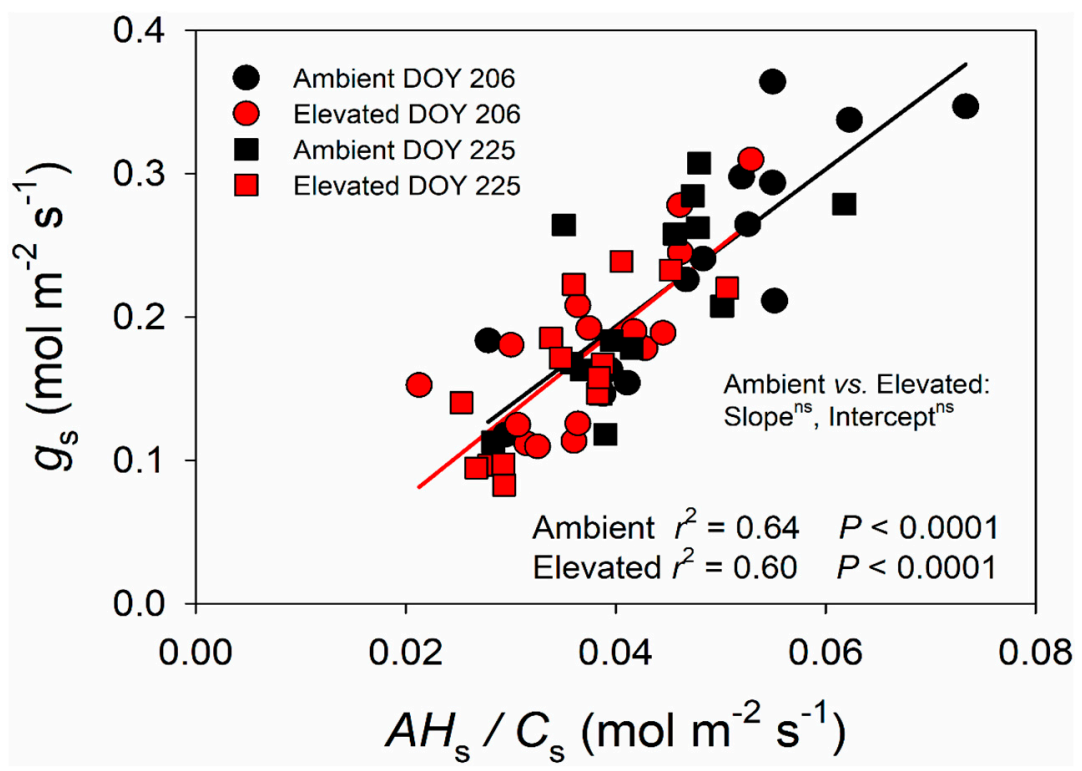

Figure 4. Relationship between stomatal conductance $\left(g_{s}\right)$ and $\frac{A H_{s}}{C_{s}}$ for switchgrass grown under ambient and elevated $\mathrm{O}_{3}$ concentrations measured on DOY 206 and DOY 225 in 2018, where $A$ is net $\mathrm{CO}_{2}$ assimilation rate $\left(\mu \mathrm{mol}\left(\mathrm{CO}_{2}\right) \mathrm{m}^{-2} \mathrm{~s}^{-1}\right), H_{\mathrm{s}}$ is relative humidity (Pa (air) Pa (Saturated) ${ }^{-1}$ ) and $C_{\mathrm{s}}$ is $\mathrm{CO}_{2}$ concentration $\left(\mathrm{Pa}\left(\mathrm{CO}_{2}\right) \mathrm{Pa}(\mathrm{air})^{-1}\right)$ at the leaf surface. The data were fitted by linear regressions.

\subsection{Leaf Respiration and Dark Adapted Chlorophyll Fluorescence Responses to Elevated $\mathrm{O}_{3}$}

Leaf dark respiration did not differ significantly between ambient and elevated $\mathrm{O}_{3}$ (Figure 5a). Although elevated $\mathrm{O}_{3}$ treated leaves had significantly greater dark adapted chlorophyll fluorescence $\left(F_{\mathrm{v}} / F_{\mathrm{m}}\right)$ than ambient leaves (Figure $\left.5 \mathrm{~b}\right)$, the $F_{\mathrm{v}} / F_{\mathrm{m}}$ values were very similar and both were higher than $0.7(0.70 \pm 0.0084$ vs. $0.72 \pm 0.0039)$ at ambient and elevated $\mathrm{O}_{3}$, indicating that leaves under both treatments were not experiencing photodamage.
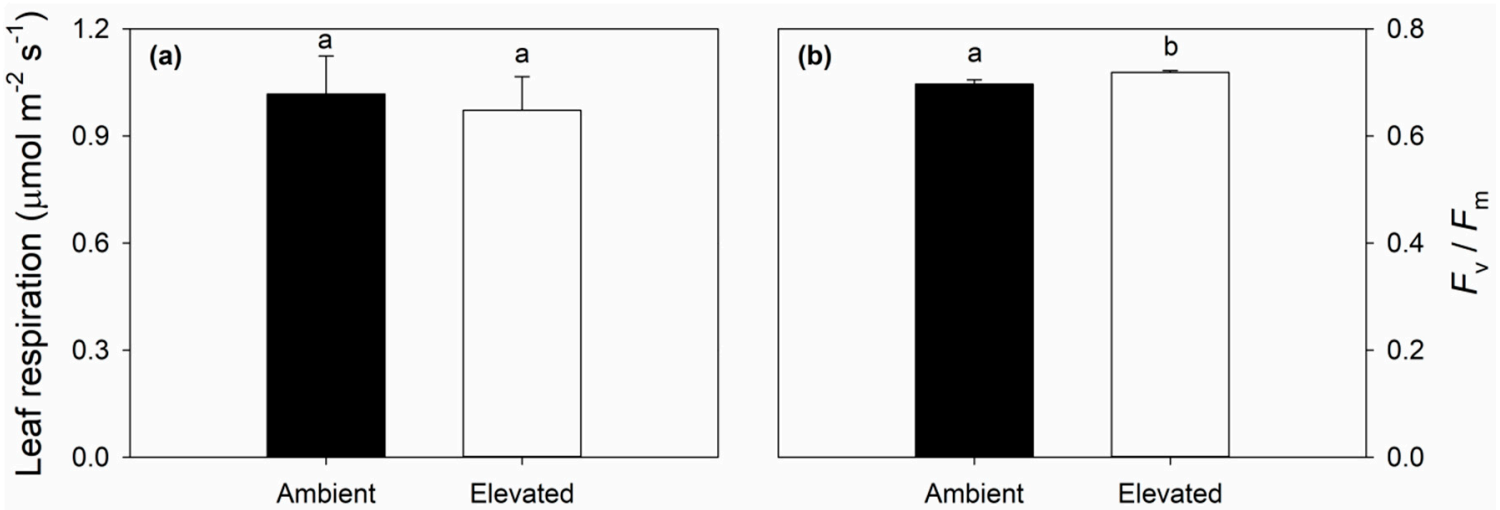

Figure 5. Leaf dark respiration (a); and maximum dark-adapted quantum yield of photosystem II $\left(F_{\mathrm{v}} / F_{\mathrm{m}}\right)(\mathbf{b})$ in ambient and elevated $\mathrm{O}_{3}$ concentration treated switchgrass leaf measured on DOY 206 in 2018. Error bars show standard errors $(n=3)$. Significant differences between ambient and elevated $\mathrm{O}_{3}$ are indicated by different letters.

\subsection{Leaf Morphology and Anatomy Were Not Altered by Elevated $\mathrm{O}_{3}$}

Leaf thickness, conduit size, inner bundle sheath size, vein size and sclerenchyma size tended to be greater in ambient compared to elevated $\mathrm{O}_{3}$, however the trends were not statistically significant (Table 1). There were no significant effects of elevated $\mathrm{O}_{3}$ on other traits of leaf anatomy (Table 1 ). In addition, elevated $\mathrm{O}_{3}$ did not alter stomatal and minor vein characteristics in switchgrass (Table 1). In both ambient and elevated $\mathrm{O}_{3}$ treatment, leaf minor vein length per leaf area was not correlated 
with stomatal density (Figure 6a), but was negatively correlated with guard cell length (Figure 6b) and stomatal pore area index (Figure 6c).

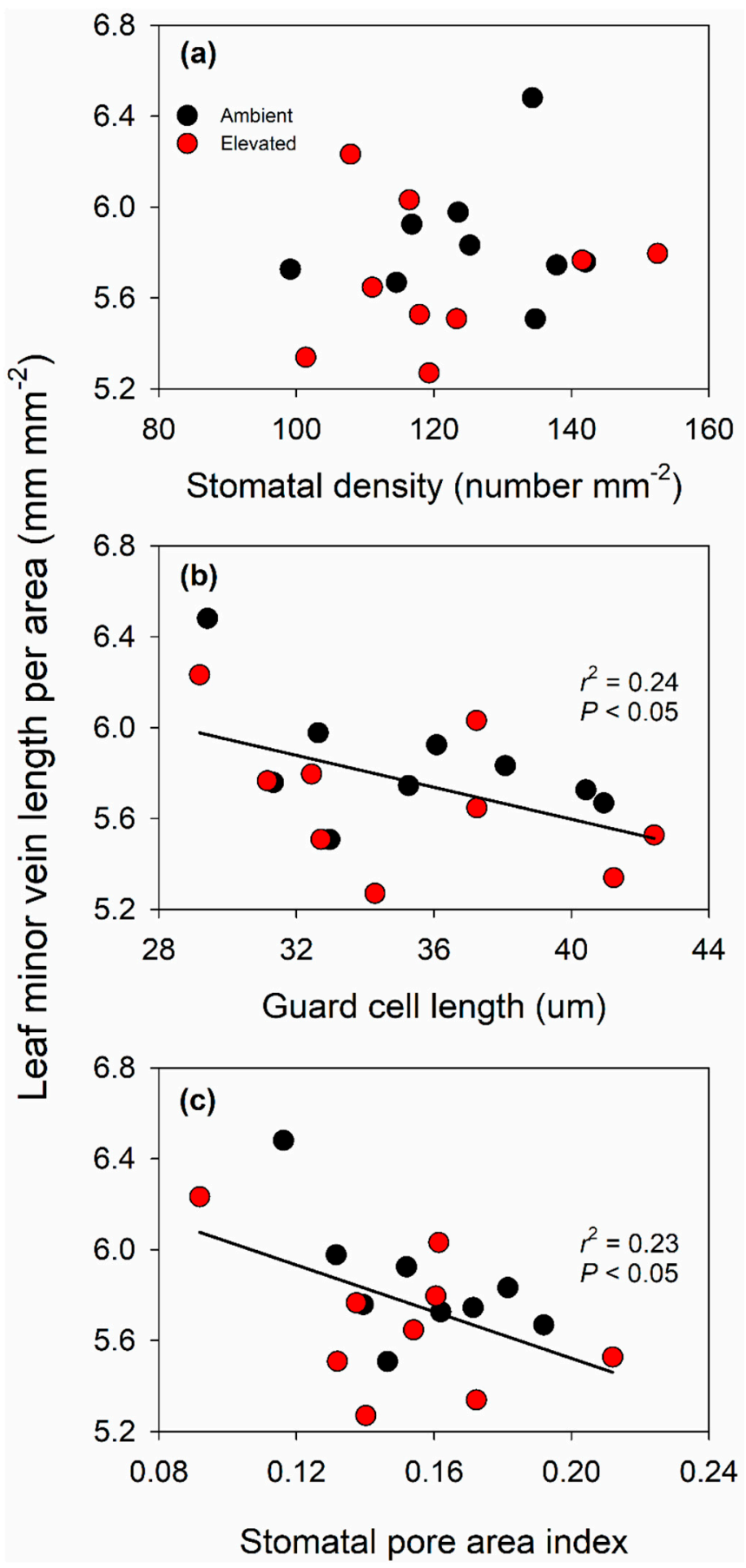

Figure 6. Relationship between leaf vein length per area and stomatal density (a); relationship between leaf vein length per area and guard cell length $(\mathbf{b})$; and relationship between leaf vein length per area and stomatal pore area index $(\mathbf{c})$. The data in $(\mathbf{b}, \mathbf{c})$ were fitted by linear regressions. 
Table 1. Leaf structural traits of switchgrass exposed to ambient and elevated $\mathrm{O}_{3}$ in 2018 . Data are presented as means $\pm \mathrm{SE}(n=3)$. Significant differences between ambient and elevated $\mathrm{O}_{3}$ are indicated by different letters.

\begin{tabular}{ccc}
\hline & Ambient $\mathbf{O}_{3}$ & Elevated $\mathbf{O}_{3}$ \\
\hline Bundle sheath density $\left(\right.$ number $\left.\mathrm{mm}^{-1}\right)$ & $5.63 \pm 0.13(\mathrm{a})$ & $5.70 \pm 0.11(\mathrm{a})$ \\
Distance between secondary vein $(\mathrm{mm})$ & $1.08 \pm 0.056(\mathrm{a})$ & $0.97 \pm 0.025(\mathrm{a})$ \\
Leaf thickness $(\mu \mathrm{m})$ & $203.3 \pm 4.99(\mathrm{a})$ & $195.9 \pm 5.81(\mathrm{a})$ \\
Interveinal distance $(\mathrm{IVD}, \mu \mathrm{m})$ & $175.2 \pm 3.56(\mathrm{a})$ & $173.1 \pm 2.65(\mathrm{a})$ \\
Conduit diameter $(\mu \mathrm{m})$ & $32.5 \pm 1.09(\mathrm{a})$ & $31.6 \pm 1.22(\mathrm{a})$ \\
Conduit size $\left(\mu \mathrm{m}^{2}\right)$ & $781.3 \pm 43.3(\mathrm{a})$ & $723.8 \pm 50.5(\mathrm{a})$ \\
Out bundle sheath size $\left(\mu \mathrm{m}^{2}\right)$ & $20885.2 \pm 891.6(\mathrm{a})$ & $20315.1 \pm 945.2(\mathrm{a})$ \\
Inner bundle sheath size $\left(\mu \mathrm{m}^{2}\right)$ & $12443.0 \pm 515.7(\mathrm{a})$ & $11928.3 \pm 625.7(\mathrm{a})$ \\
Vein size $\left(\mu \mathrm{m}^{2}\right)$ & $4263.3 \pm 248.1(\mathrm{a})$ & $4034.5 \pm 289.0(\mathrm{a})$ \\
Colorless cell size $\left(\mu \mathrm{m}^{2}\right)$ & $336.2 \pm 21.4(\mathrm{a})$ & $364.2 \pm 33.1(\mathrm{a})$ \\
Upper epidermis cell size $\left(\mu \mathrm{m}^{2}\right)$ & $141.0 \pm 5.52(\mathrm{a})$ & $143.9 \pm 6.87(\mathrm{a})$ \\
Lower epidermis cell size $\left(\mu \mathrm{m}^{2}\right)$ & $205.9 \pm 11.4(\mathrm{a})$ & $200.9 \pm 14.0(\mathrm{a})$ \\
Motor cell size $\left(\mu \mathrm{m}^{2}\right)$ & $767.9 \pm 39.6(\mathrm{a})$ & $794.9 \pm 50.7(\mathrm{a})$ \\
Sclerenchyma size $\left(\mu \mathrm{m}^{2}\right)$ & $755.4 \pm 43.2(\mathrm{a})$ & $657.5 \pm 50.4(\mathrm{a})$ \\
Stomatal density $\left(\mathrm{mm}^{-2}\right)$ & $125.3 \pm 4.55(\mathrm{a})$ & $121.1 \pm 5.42(\mathrm{a})$ \\
Guard cell length $\left(\mu \mathrm{m}^{2}\right)$ & $35.2 \pm 1.34(\mathrm{a})$ & $35.3 \pm 1.51(\mathrm{a})$ \\
Stomatal pore area index $\left(\mathrm{SPI}^{2} \times 10^{-2}\right)$ & $0.15 \pm 0.0081(\mathrm{a})$ & $0.15 \pm 0.011(\mathrm{a})$ \\
Vein density $\left(\mathrm{mm} \mathrm{mm}^{-2}\right)$ & $5.85 \pm 0.092(\mathrm{a})$ & $5.68 \pm 0.10(\mathrm{a})$ \\
\hline
\end{tabular}

\subsection{No Changes in Biomass and Nutrient Composition between Ambient and Elevated $\mathrm{O}_{3}$}

There was no significant effect of elevated $\mathrm{O}_{3}$ on leaf area, biomass or tiller number in switchgrass after growing in chronic elevated $\mathrm{O}_{3}$ for two months (Table 2). Additionally, there was no significant effect of elevated $\mathrm{O}_{3}$ on leaf mass per area (LMA) (64.8 \pm 1.12 vs. $\left.69.4 \pm 2.60\right)$ (Table 2). Leaf and stem $\mathrm{N}$ content, and leaf and stem C:N were also unchanged by elevated $\mathrm{O}_{3}$ (Table 2). Elevated $\mathrm{O}_{3}$ led to a significant decrease in potassium $(\mathrm{K})$ and in leaf stable carbon isotope composition $\left(\delta^{13} \mathrm{C}\right)$ (Table 3$)$. However, no changes in the content of micronutrients or leaf stable nitrogen isotope composition $\left(\delta^{15} \mathrm{~N}\right)$ were observed (Table 3$)$.

Table 2. Leaf and stem biomass, $\mathrm{N}$ content and C: $\mathrm{N}$ of switchgrass exposed to ambient and elevated $\mathrm{O}_{3}$ in 2018. Data are presented as means $\pm \mathrm{SE}(n=3)$. Significant differences between ambient and elevated $\mathrm{O}_{3}$ are indicated by different letters.

\begin{tabular}{ccc}
\hline & ${\text { Ambient } \mathbf{O}_{3}}$ & Elevated $\mathbf{O}_{3}$ \\
\hline Leaf area $\left(\mathrm{cm}^{2}\right.$ plant $\left.^{-1}\right)$ & $5624.5 \pm 659.6(\mathrm{a})$ & $6681.1 \pm 875.3(\mathrm{a})$ \\
Leaf biomass $\left(\mathrm{g} \mathrm{plant}^{-1}\right)$ & $36.4 \pm 4.28(\mathrm{a})$ & $44.1 \pm 4.58(\mathrm{a})$ \\
Leaf mass per area $\left(\mathrm{LMA}, \mathrm{g} \mathrm{m}^{-2}\right)$ & $64.8 \pm 1.12(\mathrm{a})$ & $69.4 \pm 2.60(\mathrm{a})$ \\
Tiller number & $31.0 \pm 2.96(\mathrm{a})$ & $32.4 \pm 2.45(\mathrm{a})$ \\
Tiller biomass $\left(\mathrm{g} \mathrm{plant}^{-1}\right)$ & $75.2 \pm 8.89(\mathrm{a})$ & $97.0 \pm 13.12(\mathrm{a})$ \\
Leaf area per tiller $\left(\mathrm{cm}^{2}\right.$ branch $\left.^{-1}\right)$ & $178.8 \pm 13.99(\mathrm{a})$ & $198.6 \pm 13.37(\mathrm{a})$ \\
Leaf mass per tiller $\left(\mathrm{g} \mathrm{plant}^{-1}\right)$ & $1.15 \pm 0.086(\mathrm{a})$ & $1.36 \pm 0.054(\mathrm{a})$ \\
Average tiller mass $(\mathrm{g})$ & $2.39 \pm 0.20(\mathrm{a})$ & $2.87 \pm 0.21(\mathrm{a})$ \\
Leaf N $(\%)$ & $2.53 \pm 0.045(\mathrm{a})$ & $2.49 \pm 0.035(\mathrm{a})$ \\
Leaf C:N & $17.8 \pm 0.29(\mathrm{a})$ & $18.1 \pm 0.24(\mathrm{a})$ \\
Stem N $(\%)$ & $1.36 \pm 0.057(\mathrm{a})$ & $1.39 \pm 0.049(\mathrm{a})$ \\
Stem C:N & $33.0 \pm 1.49(\mathrm{a})$ & $32.2 \pm 1.23(\mathrm{a})$ \\
\hline
\end{tabular}


Table 3. Leaf nutrient composition, stable carbon $\left(\delta^{13} \mathrm{C}\right)$ and nitrogen $\left(\delta^{15} \mathrm{~N}\right)$ isotope composition of switchgrass exposed to ambient and elevated $\mathrm{O}_{3}$ in 2018. Data are presented as means $\pm \mathrm{SE}(n=3)$. Significant differences between ambient and elevated $\mathrm{O}_{3}$ are indicated by different letters.

\begin{tabular}{|c|c|c|}
\hline & Ambient $\mathrm{O}_{3}$ & Elevated $\mathrm{O}_{3}$ \\
\hline $\mathrm{Mg}\left(\mathrm{mg} \mathrm{kg}^{-1}\right)$ & $5079.1 \pm 229.8(\mathrm{a})$ & $5617.5 \pm 285.2(\mathrm{a})$ \\
\hline $\mathrm{P}\left(\mathrm{mg} \mathrm{kg}^{-1}\right)$ & $2466.8 \pm 65.9(\mathrm{a})$ & $2732.1 \pm 146.9(\mathrm{a})$ \\
\hline $\mathrm{S}\left(\mathrm{mg} \mathrm{kg}^{-1}\right)$ & $2326.0 \pm 77.0$ (a) & $2316.1 \pm 86.1(\mathrm{a})$ \\
\hline $\mathrm{K}\left(\mathrm{mg} \mathrm{kg}^{-1}\right)$ & $18695.6 \pm 737.5(\mathrm{a})$ & $16245.0 \pm 688.3(b)$ \\
\hline $\mathrm{Ca}\left(\mathrm{mg} \mathrm{kg}^{-1}\right)$ & $5994.7 \pm 387.8$ (a) & $7590.4 \pm 685.4(\mathrm{a})$ \\
\hline $\mathrm{B}\left(\mathrm{mg} \mathrm{kg}^{-1}\right)$ & $3.43 \pm 0.10(\mathrm{a})$ & $3.71 \pm 0.086(a)$ \\
\hline $\operatorname{Mn}\left(\mathrm{mg} \mathrm{kg}^{-1}\right)$ & $65.1 \pm 10.7(a)$ & $52.5 \pm 9.91(\mathrm{a})$ \\
\hline $\mathrm{Fe}\left(\mathrm{mg} \mathrm{kg}^{-1}\right)$ & $459.7 \pm 61.1(\mathrm{a})$ & $457.2 \pm 43.2(\mathrm{a})$ \\
\hline Ni (mg kg-1) & $3.18 \pm 0.26(a)$ & $2.80 \pm 0.23(\mathrm{a})$ \\
\hline $\mathrm{Cu}\left(\mathrm{mg} \mathrm{kg}^{-1}\right)$ & $9.78 \pm 0.43(\mathrm{a})$ & $9.07 \pm 0.33(\mathrm{a})$ \\
\hline $\mathrm{Zn}\left(\mathrm{mg} \mathrm{kg}^{-1}\right)$ & $27.6 \pm 2.18(\mathrm{a})$ & $27.4 \pm 2.21(\mathrm{a})$ \\
\hline $\mathrm{Mo}\left(\mathrm{mg} \mathrm{kg}^{-1}\right)$ & $1.17 \pm 0.069$ (a) & $1.27 \pm 0.24(\mathrm{a})$ \\
\hline $\mathrm{Na}\left(\mathrm{mg} \mathrm{kg}^{-1}\right)$ & $106.3 \pm 11.5$ (a) & $142.7 \pm 23.5(\mathrm{a})$ \\
\hline $\mathrm{V}\left(\mathrm{mg} \mathrm{kg}^{-1}\right)$ & $0.36 \pm 0.021(\mathrm{a})$ & $0.36 \pm 0.014(a)$ \\
\hline $\mathrm{Co}\left(\mathrm{mg} \mathrm{kg}^{-1}\right)$ & $0.13 \pm 0.012(a)$ & $0.11 \pm 0.0080(\mathrm{a})$ \\
\hline$\delta^{13} \mathrm{C}(\%)$ & $-12.22 \pm 0.060(\mathrm{a})$ & $-12.49 \pm 0.080(b)$ \\
\hline$\delta^{15} \mathrm{~N}(\% o)$ & $4.04 \pm 0.46(\mathrm{a})$ & $5.35 \pm 0.78(\mathrm{a})$ \\
\hline
\end{tabular}

\section{Discussion}

\subsection{Impact of Elevated $\mathrm{O}_{3}$ on Photosynthesis and Stomatal Conductance}

It is well known that elevated $\mathrm{O}_{3}$ negatively influences the growth, development, production and yield of $\mathrm{C}_{3}$ plants. In contrast, there is a much more limited body of information about the impacts of elevated $\mathrm{O}_{3}$ on photosynthesis and performance of $\mathrm{C}_{4}$ species. Here, we studied the effects of elevated $\mathrm{O}_{3}$ on leaf photosynthetic and structural traits using a promising $\mathrm{C}_{4}$ bioenergy crop, switchgrass, which was grown under season-long elevated $\mathrm{O}_{3}$ in the field with FACE technology. We found that elevated $\mathrm{O}_{3}$ significantly reduced midday $A$ and $g_{\mathrm{s}}$ (Figure 2), consistent with past observations in maize [50-54] and sugarcane [56,57]. Additionally, maximum photosynthetic capacity $\left(V_{\max }\right)$ was lower in elevated $\mathrm{O}_{3}$ (Figure 3), also consistent with previous observations in maize [53]. However, intercellular $\mathrm{CO}_{2}$ concentration $\left(C_{\mathrm{i}}\right)$ and instantaneous water use efficiency (iWUE) did not statistically differ between ambient and elevated $\mathrm{O}_{3}$ (Figure 1), and the slope between $g_{\mathrm{s}}$ and $\frac{A H_{s}}{\mathrm{C}_{s}}$ was also different (Figure 4). In $\mathrm{C}_{3}$ species, it is commonly observed that elevated $\mathrm{O}_{3}$ impairs photosynthetic capacity, with reduced $g_{\mathrm{s}}$ being a consequence rather than a driver of lower $A[29,60]$. Additionally, stomata can be damaged by $\mathrm{O}_{3}$ exposure leading to sluggish response to other environmental parameters [61]. Thus, in elevated $\mathrm{O}_{3}$, greater $g_{\mathrm{s}}$ may be required to support a given $A$, which decreases water use efficiency [61]. In switchgrass, this was not observed, and both $A$ and $g_{s}$ were proportionally affected, leading to no change in iWUE or the slope of the BWB model. To our knowledge, this is the first study to test how the slope of the BWB is affected by elevated $\mathrm{O}_{3}$ in $\mathrm{C}_{4}$ species, but, in rice, elevated $\mathrm{O}_{3}$-induced changes in the $\mathrm{BWB}$ relationship were observed in $\mathrm{O}_{3}$ sensitive cultivars, but not more tolerant cultivars [43]. In sugarcane, the degree to which $A$ and $g_{s}$ were affected by elevated $\mathrm{O}_{3}$ varied with genotype [57], thus it is possible that slope of the BWB relationship was also impacted, but this was not explicitly tested. In this study on switchgrass, only one genotype was investigated, but it is also possible that there is intraspecific genetic variation in $\mathrm{O}_{3}$ response within switchgrass.

Long-term exposure to elevated $\mathrm{O}_{3}$ stress often significantly reduces either light- and/or dark-adapted chlorophyll fluorescence parameters [39-42]. In switchgrass, the effects of elevated $\mathrm{O}_{3}$ on fluorescence were inconsistent. Reductions in $F_{\mathrm{v}}{ }^{\prime} / F_{\mathrm{m}}{ }^{\prime}$ were only found on DOY 206, while quantum yield of PSII (TPSII) and electron transport rate (ETR) were reduced later in the growing season. No changes in photochemical quenching $(q \mathrm{P})$ were observed in $\mathrm{O}_{3}$-exposed leaves (Figure 2), indicating 
PSII photochemistry did not change in the $\mathrm{O}_{3}$-treated leaves of switchgrass. Although maximum dark-adapted quantum yield of photosystem II $\left(F_{\mathrm{v}} / F_{\mathrm{m}}\right)$ was significantly increased in $\mathrm{O}_{3}$-exposed leaves, both values of ambient and elevated $\mathrm{O}_{3}$ were higher than 0.7 (Figure $5 b$ ), which further confirmed that PSII reaction center was not damaged by elevated $\mathrm{O}_{3}$. Overall, PSII photochemistry in switchgrass was not strongly impacted by $\mathrm{O}_{3}$ stress, even though there were reductions on photosynthetic capacity and stomatal conductance.

\subsection{Effect of Elevated $\mathrm{O}_{3}$ on Leaf Structure}

Leaf structural traits such as leaf mass per area (LMA) are predicted to contribute to $\mathrm{O}_{3}$ sensitivity among species [62,63], but the effects of elevated $\mathrm{O}_{3}$ on leaf anatomical traits have not been well studied, especially in $\mathrm{C}_{4}$ species. There was no significant effect of $\mathrm{O}_{3}$ in switchgrass foliar anatomy (Table 1), which may result from the unique leaf structural features of $\mathrm{C}_{4}$ species including large bundle sheath volumes that enable greater Rubisco content than needed for photosynthetic saturation [64]. Feng et al. (2018) showed that tree species with greater LMA tended to have more $\mathrm{O}_{3}$ tolerance [63]. Switchgrass has greater LMA than maize [53], and showed greater tolerance to $\mathrm{O}_{3}$, although only a single genotype of switchgrass was investigated. A more thorough characterization of the relationship between LMA and $\mathrm{O}_{3}$ tolerance in grasses would be needed to test if the relationship found in trees translates to other functional groups.

Leaf minor vein density is an important determinant of leaf water and nutrient transport efficiency, which together are essential for hydraulic conductance and stomatal function. Previous work in other species reported that elevated $\mathrm{O}_{3}$ decreases whole plant hydraulic conductance [65], but studies have not examined how elevated $\mathrm{O}_{3}$ impacts the anatomical determinants of hydraulic conductance such as leaf minor vein density. Under temperature stress, leaf minor vein density and stomatal density increased in parallel supporting greater leaf hydraulic conductance [66]. Other studies have also shown that the correlation between leaf minor vein density and stomatal density varies with environmental factors including temperature, atmospheric humidity and altitude [66-69]. In this study on switchgrass, there was no correlation between leaf minor vein density and stomatal density (Figure 6a), but there was an unexpected negative correlation between leaf minor vein density and guard cell length as well as between the leaf minor vein density and stomatal pore area index (Figure $6 \mathrm{~b}, \mathrm{c}$ ). Across a diverse range of species, leaf minor vein density is positively correlated with stomatal density [70], however the opposite pattern of what was observed here. Study of additional genotypes and conditions would be needed to more broadly understand this relationship in switchgrass.

\subsection{Effect of Elevated $\mathrm{O}_{3}$ on Biomass and Nutrient Composition}

Many previous studies have shown that elevated $\mathrm{O}_{3}$ negatively affects both biomass and yield production across plant species $[27,29]$. A review of woody species estimated that elevated $\mathrm{O}_{3}$ reduces biomass by $7 \%$ across diverse tree species [28]. Similarly, a review of the effects of elevated $\mathrm{O}_{3}$ on reproductive processes suggested that yield and seed weight are reduced to a similar extent in both $\mathrm{C}_{3}$ and $\mathrm{C}_{4}$ species [71]. However, few $\mathrm{C}_{4}$ species have been studied in detail, and most of the prior work focused on maize. In tobacco, growth at high $\mathrm{N}$ treatment protected from $\mathrm{O}_{3}$ damage [72] suggesting that the negative impacts of $\mathrm{O}_{3}$ on biomass may be improved by soil nutrient conditions. Similar results were observed in switchgrass which was grown under high fertility at the FACE site in this study (Table 2). No differences in leaf and stem $\mathrm{N}$ content or above-ground biomass were observed in ambient and elevated $\mathrm{O}_{3}$. Given the decrease in photosynthesis, it is somewhat surprising that no differences in above-ground biomass were observed. However, in wheat, root biomass is reduced more than shoot biomass at elevated $\mathrm{O}_{3}$ [27], and it is possible that there was a change in allocation in switchgrass at elevated $\mathrm{O}_{3}$ as well.

Other nutrients including magnesium $(\mathrm{Mg})$, phosphorus $(\mathrm{P})$, sulfur $(\mathrm{S})$, potassium $(\mathrm{K})$, zinc $(\mathrm{Zn})$, calcium $(\mathrm{Ca})$ and iron $(\mathrm{Fe})$ are important components of the photosynthetic apparatus and reactions [73-75] and also impact the efficiency of biomass combustion systems [76]. Here, a significant 
decrease in elevated $\mathrm{O}_{3}$ was only observed for $\mathrm{K}$ (Table 3), which may be associated with reductions in net $\mathrm{CO}_{2}$ assimilation $(A)$ and stomatal conductance $\left(g_{\mathrm{s}}\right)$ (Figure 1) [75]. Indeed, changes in nutrient composition highly depend on the soil properties and on the $\mathrm{O}_{3}$ impact on plant metabolism [77-79]. There was a significant, but small, reduction in leaf stable carbon isotope composition $\left(\delta^{13} \mathrm{C}\right)$ but no change in nitrogen isotope composition $\left(\delta^{15} \mathrm{~N}\right)$ at elevated $\mathrm{O}_{3}$. Generally, $\delta^{13} \mathrm{C}$ is positively correlated with water use efficiency [80-82], while $\delta^{15} \mathrm{~N}$ serves as an indicator of plant $\mathrm{N}$ acquisition, fixation and cycling [83-85]. Both $\delta^{13} \mathrm{C}$ and $\delta^{15} \mathrm{~N}$ are strongly controlled by environmental conditions. Although elevated $\mathrm{O}_{3}$ did not alter iWUE on DOY 206 and DOY 225 (Figure 1 and Table 1), decreased $\delta^{13} \mathrm{C}$ suggests that there was an accumulated effect of elevated $\mathrm{O}_{3}$ over the life-time of the leaf, albeit small. As discussed above, plants grown in sufficient $\mathrm{N}$ were not compromised by elevated $\mathrm{O}_{3}$, which could partially explain the limited effects of elevated $\mathrm{O}_{3}$ on $\delta^{15} \mathrm{~N}$ [72].

\subsection{Implications for Bioenergy Feedstock Development}

Although a successful bioenergy industry will require high productivity and yield stability of bioenergy feedstocks, how the bioenergy crops acclimate to a rapidly changing, more polluted environment should be considered seriously. Our results provide evidence that switchgrass exhibits $\mathrm{O}_{3}$ tolerance, and suggest that $\mathrm{C}_{4}$ bioenergy crops including maize and switchgrass differ in $\mathrm{O}_{3}$ tolerance. However, the year of our experiment was extremely wet, and previous work in maize also showed that $\mathrm{O}_{3}$ sensitivity was greater in dry years [31], thus additional side-by-side experiments with more genotypes and species are needed for a definitive comparison. In natural environments ambient $\mathrm{O}_{3}$ concentrations strongly vary over the land surface throughout the day and over the season, resulting in geographic variation in $\mathrm{O}_{3}$ pollution. Therefore, understanding variation in $\mathrm{C}_{4}$ bioenergy feedstock responses to elevated $\mathrm{O}_{3}$ could be used to better place specific feedstocks on a dynamic landscape.

\section{Materials and Methods}

\subsection{Field Site, Plant Material and Growth Condition}

The study was conducted at the Free Air Concentration Enrichment (FACE) facility in Champaign, IL, USA (www.igb.illinois.edu/soyface/, $40^{\circ} 02^{\prime} \mathrm{N}, 88^{\circ} 14^{\prime} \mathrm{W}$ ) in 2018. Six plots in octagonal shape of $20 \mathrm{~m}$ diameter were designed for this study: three at ambient $\mathrm{O}_{3}$ concentration $\left(30-50 \mathrm{nmol} \mathrm{mol}^{-1}\right)$ and three fumigated to elevated $\mathrm{O}_{3}$ concentration $\left(\sim 100 \mathrm{nmol} \mathrm{mol}^{-1}\right)$. The weather conditions including daily maximum and minimum air temperature, averaged light intensity (9:00-18:00), precipitation, averaged daily relative humidity and $\mathrm{O}_{3}$ concentration (10:00-18:00) during growing season of 2018 were monitored by an on-site weather station at the FACE facility and shown in Figure 7.

Seedlings of switchgrass (Panicum virgatum Kanlow, generously provided by DK Lee, University of Illinois at Urbana-Champaign) were transplanted in the central part of each plot on 24 May (DOY 144) in 2018. Elevated $\mathrm{O}_{3}$ plots were fumigated on 25 May (DOY 145) in 2018 and followed the protocol described in detail by Morgan et al. (2004) [86] and Yendrek et al. [53,54]. Elevated $\mathrm{O}_{3}$ fumigation was carried out using the $\mathrm{O}_{3}$-enriched air that was delivered to and released within the experimental plots with FACE technology. $\mathrm{O}_{3}$ was generated by an $\mathrm{O}_{3}$ generator (CFS-3 2G; Ozonia) using pure oxygen and monitored by a chemiluminescence $\mathrm{O}_{3}$ sensor (Model 49i, Thermo Scientific, Massachusetts, USA) that connected to the tube pumping air from the central point of plot. Fumigation was applied for $8 \mathrm{~h}$ per day from 10:00 to 18:00 when leaves were not too wet and when wind speed was not too low, with the target $\mathrm{O}_{3}$ concentration of $100 \mathrm{~nL} \mathrm{~L}^{-1}$ at the central point of elevated plots. $\mathrm{O}_{3}$ fumigation was stopped on 13 August (DOY 225) in 2018 once the second round of midday photosynthesis measurements were finished (Figure 7e). In 2018, the 1 min average $\mathrm{O}_{3}$ concentrations within the elevated plots were within $20 \%$ of the target concentration $81.6 \%$ of the time. 

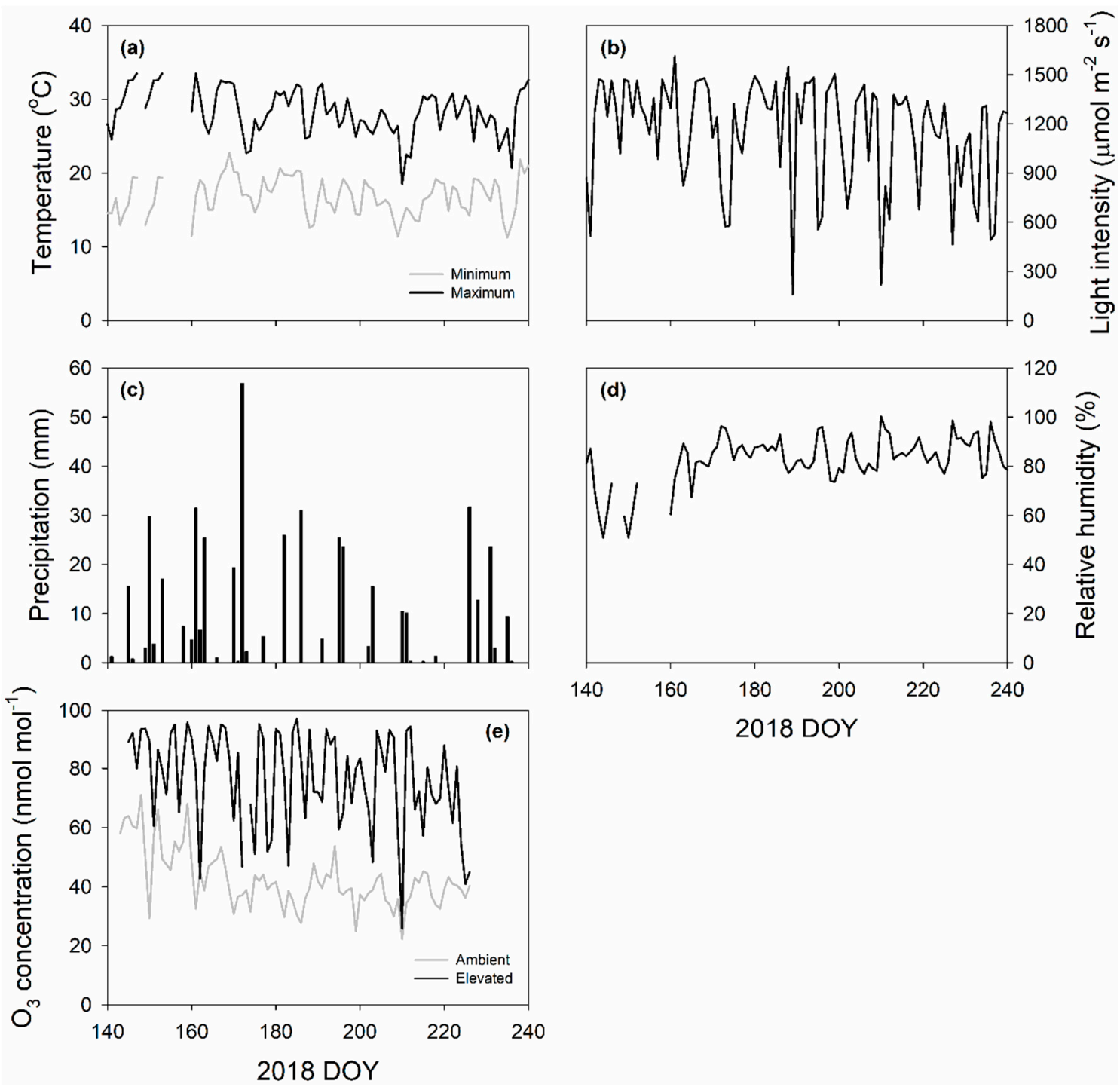

Figure 7. Daily maximum and minimum air temperature (a); averaged light intensity (b); precipitation (c); averaged daily relative humidity (d); and $\mathrm{O}_{3}$ concentration (e) during growing season in 2018 measured by an on-site weather station at the FACE facility in Champaign, IL.

\subsection{Leaf Midday Gas Exchange, Chlorophyll Fluorescence and $A / C_{i}$ Curve}

In situ midday gas exchange and chlorophyll fluorescence measurements were made on fully expanded leaves between 11:00 and 14:00 on sunny days of 25 July (DOY 206) and 13 August (DOY 225) in 2018. The net $\mathrm{CO}_{2}$ assimilation rates $(A)$, stomatal conductance to water vapor $\left(g_{\mathrm{s}}\right)$, intercellular $\mathrm{CO}_{2}$ concentration $\left(C_{\mathrm{i}}\right)$ and chlorophyll fluorescence $\left(F_{\mathrm{v}}{ }^{\prime} / F_{\mathrm{m}}{ }^{\prime}, \Phi_{\mathrm{PSII}}\right.$, ETR, and $\left.\mathrm{qP}\right)$ under illumination were measured with a portable photosynthesis system (LI 6400, LICOR Biosciences, Lincoln, NE, USA) following previously published protocols $[53,87,88]$. Briefly, the environmental conditions within the leaf cuvette were set to match ambient conditions: leaf cuvette temperature was $29^{\circ} \mathrm{C}, \mathrm{CO}_{2}$ concentration was $400 \mu \mathrm{mol} \mathrm{mol}^{-1}$, light intensity at the leaf surface was $1950 \mu \mathrm{mol} \mathrm{m}^{-2} \mathrm{~s}^{-1}$ and relative humidity was $60 \%$ for the DOY 206 ; leaf cuvette temperature was $31^{\circ} \mathrm{C}, \mathrm{CO}_{2}$ concentration was $420 \mu \mathrm{mol} \mathrm{mol}^{-1}$, light intensity at the leaf surface was $1750 \mu \mathrm{mol} \mathrm{m}^{-2} \mathrm{~s}^{-1}$ and relative humidity was $60 \%$ for DOY 225, 2018. The measurement was performed when photosynthesis had stabilized, typically 3-5 min after leaf enclosure. Considering the heterogeneity of physiology and structure within a given leaf $[89,90]$, we measured photosynthesis and other functional traits (see below) in the middle 
part of all leaves. In all cases, $4-5$ leaves of different individuals within each plot were measured, and were averaged for analyses. The instantaneous water use efficiency (iWUE) was calculated as $A / g_{s}$.

Three sun-exposed leaves of different individuals within each plot were selected to measure the response of $A$ to $C_{\mathrm{i}}$ using a LI-6400. Predawn on DOY 206, leaves were excised and recut immediately under water to prevent leaf water potential decrease, chloroplast inorganic phosphate concentration or maximum photosystem II efficiency decrease [91]. With the cut end immersed, leaves were quickly transported to the laboratory where they were exposed to ambient $\mathrm{CO}_{2}$ concentration and saturating light levels to achieve a steady-state. The middle part of the leaf was then enclosed in cuvette and measurements were initiated at a $\mathrm{CO}_{2}$ concentration of $400 \mu \mathrm{mol} \mathrm{mol}{ }^{-1}$, air temperature of $25^{\circ} \mathrm{C}$, light intensity of $1800 \mu \mathrm{mol} \mathrm{m} \mathrm{m}^{-2} \mathrm{~s}^{-1}$ and relative humidity of $60 \% . \mathrm{CO}_{2}$ concentration within the cuvette was then changed sequentially as follows: 400,300, 200, 100, 50, 400, 500, 600, 800, 1000, and $1200 \mu \mathrm{mol} \mathrm{mol}{ }^{-1}$. The maximum carboxylation capacity of phosphoenolpyruvate $\left(V_{\mathrm{pmax}}\right)$ and $\mathrm{CO}_{2}$ saturated photosynthetic capacity $\left(V_{\max }\right)$ were calculated according to Farquhar et al. (1980), von Caemmerer (2000) and Markelz et al. (2011) [92-94].

\subsection{Ball-Woodrow-Berry Relationship}

The Ball-Woodrow-Berry (BWB) relationship was calculated as:

$$
g_{s}=a \frac{A H_{s}}{C_{s}}+b
$$

where $g_{\mathrm{s}}$ is stomatal conductance to water vapor $\left(\mathrm{mol}\left(\mathrm{H}_{2} \mathrm{O}\right) \mathrm{m}^{-2} \mathrm{~s}^{-1}\right) ; A$ is net $\mathrm{CO}_{2}$ assimilation rate $\left(\mu \mathrm{mol}\left(\mathrm{CO}_{2}\right) \mathrm{m}^{-2} \mathrm{~s}^{-1}\right) ; H_{\mathrm{s}}$ and $C_{\mathrm{s}}$ are relative humidity $\left(\mathrm{Pa}\right.$ (air) $\mathrm{Pa}$ (Saturated) ${ }^{-1}$ ) and $\mathrm{CO}_{2}$ concentration $\left(\mathrm{Pa}\left(\mathrm{CO}_{2}\right) \mathrm{Pa}(\text { air })^{-1}\right)$ at the leaf surface, respectively; and $a$ and $b$ are the slope $\left(\mathrm{mol}\left(\mathrm{H}_{2} \mathrm{O}\right) \mathrm{mol}\left(\mathrm{CO}_{2}\right)^{-1}\right)$ and intercept $\left(\mathrm{mol}\left(\mathrm{H}_{2} \mathrm{O}\right) \mathrm{m}^{-2} \mathrm{~s}^{-1}\right)$ of the BWB relationship, respectively [43,48].

$H_{\mathrm{s}}$ was calculated as:

$$
H_{s}=\frac{E_{s}}{E_{\text {sat }}}
$$

where $E_{\mathrm{s}}$ is the partial pressure $(\mathrm{Pa})$ of vapor at the leaf surface and $E_{\mathrm{sat}}$ is the partial pressure $(\mathrm{Pa})$ of vapor at saturation.

$E_{\mathrm{s}}$ was determined as:

$$
T_{r}=g_{s} \frac{E_{i}-E_{s}}{P}
$$

where $T_{\mathrm{r}}$ is transpiration $\left(\mathrm{mol}\left(\mathrm{H}_{2} \mathrm{O}\right) \mathrm{m}^{-2} \mathrm{~s}^{-1}\right)$ and $P$ is air pressure $(\mathrm{Pa})$. $E_{\mathrm{i}}$ is the partial pressure of vapor $(\mathrm{Pa})$ at substomatal cavity and is assumed to be saturated:

$$
E_{i}=E_{\mathrm{sat}}=611 \exp \left(\frac{\lambda}{R}\left(\frac{1}{273.15}-\frac{1}{T_{l}}\right)\right)
$$

where $\lambda$ and $R$ are the latent heat of vaporization and (set at 2,500,000 $\mathrm{J} \mathrm{kg}^{-1}$ ) and the gas constant of vapor and (set at $461 \mathrm{~J} \mathrm{~kg}^{-1} \mathrm{~K}^{-1}$ ) [40], respectively, and $T_{1}$ is leaf temperature (K).

$C_{\mathrm{s}}$ was determined by the following equation:

$$
A=\frac{g_{s}}{1.6}\left(C_{s}-C_{i}\right)
$$

where 1.6 is the ratio of conductance for $\mathrm{H}_{2} \mathrm{O}$ to that for $\mathrm{CO}_{2}$ and has dimensions of $\left(\left(\mathrm{mol}\left(\mathrm{H}_{2} \mathrm{O}\right) \mathrm{m}^{-2} \mathrm{~s}^{-1}\right) /\right.$ $\left(\mathrm{mol}\left(\mathrm{CO}_{2}\right) \mathrm{m}^{-2} \mathrm{~s}^{-1}\right)$ ) and $C_{\mathrm{i}}$ is intercellular $\mathrm{CO}_{2}$ concentration $\left(\mathrm{Pa}\left(\mathrm{CO}_{2}\right) \mathrm{Pa}(\mathrm{air})^{-1}\right)$.

The values of $A, g_{\mathrm{s}}, T_{\mathrm{r}}, C_{\mathrm{i}}, P$ and $T_{1}$ were observed from a portable photosynthesis analyzer Licor-6400. The slope $a$ and intercept $b$ of the BWB relationship were estimated using linear regression with observed $g_{\mathrm{s}}$ and calculated $\frac{A H_{s}}{C_{s}}$. 


\subsection{Dark Respiration and Dark-Adapted Chlorophyll Fluorescence}

Leaf respiration rates and chlorophyll fluorescence under dark were also measured using the LI-6400. Immediately after each A/Ci curve was completed, the leaf was removed from the cuvette and kept in the cabinet under dark for at least $50 \mathrm{~min}$. Environmental controls inside the cuvette were maintained to match the ambient conditions: leaf cuvette temperature was $27^{\circ} \mathrm{C}, \mathrm{CO}_{2}$ concentration was $400 \mu \mathrm{mol} \mathrm{mo}{ }^{-1}$, relative humidity was $60 \%$ but light intensity at the leaf surface was $0 \mu \mathrm{mol} \mathrm{m} \mathrm{m} \mathrm{s}^{-1}$. Leaf dark respiration was measured after readings stabilized, typically 3-10 min after leaf enclosure. To examine the effects of elevated $\mathrm{O}_{3}$ on photosystem II (PS II) activity, dark-adapted chlorophyll fluorescence was measured. Following the respiration rates measurements, the leaf was further illuminated with a saturating irradiance $\left(>7000 \mu \mathrm{mol} \mathrm{m}{ }^{-2} \mathrm{~s}^{-1}\right)$ to measure the minimum fluorescence yield $\left(F_{0}\right)$ and the maximum dark-adapted fluorescence yield $\left(F_{\mathrm{m}}\right)$. The spatially averaged maximum dark-adapted quantum yield of photosystem II (PSII), $F_{\mathrm{v}} / F_{\mathrm{m}}$ was calculated as the ratio of $\left(F_{\mathrm{m}}-F_{0}\right)$ to $F_{\mathrm{m}}$.

\subsection{Leaf Anatomy}

Immediately after each dark-adapted chlorophyll fluorescence measurement was completed, leaf samples of $16 \mathrm{~cm}^{2}$ were excised with a razor blade and stored in $70 \%$ ethanol for further analysis in the laboratory. For each leaf sample, three hand-cut transverse sections were viewed under a microscope (Leica DM 2000, Leica Microsystems, Wetzlar, Germany) and imaged using a digital camera (SPOT Insight $4 \mathrm{Mp}$ CCD, Diagnostic Instruments, Inc. USA). Using an image analysis software (Image J, National Institutes of Health, Bethesda, MD, USA), the following leaf structural traits were measured followed previous published methods [95,96]: bundle sheath density (number $\mathrm{mm}^{-1}$ ), distance between secondary vein $(\mathrm{mm})$, leaf thickness $(\mu \mathrm{m})$, interveinal distance (IVD, $\mu \mathrm{m})$, conduit diameter $(\mu \mathrm{m})$, conduit size $\left(\mu \mathrm{m}^{2}\right)$, out bundle sheath size $\left(\mu \mathrm{m}^{2}\right)$, inner bundle sheath size $\left(\mu \mathrm{m}^{2}\right)$, vein size $\left(\mu \mathrm{m}^{2}\right)$, colorless cell size $\left(\mu \mathrm{m}^{2}\right)$, upper epidermis cell size $\left(\mu \mathrm{m}^{2}\right)$, lower epidermis cell size $\left(\mu \mathrm{m}^{2}\right)$, motor cell size $\left(\mu \mathrm{m}^{2}\right)$, and sclerenchyma size $\left(\mu \mathrm{m}^{2}\right)$.

To measure stomatal density and guard cell length, clear nail polish impressions were collected from abaxial surface of the lamina using other leaf discs from the same leaf sample used for leaf anatomical measurement and viewed and imaged under microscope. The stomatal pore area index

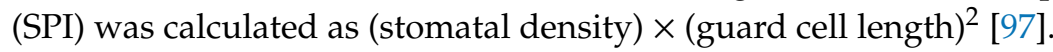

Using a $\sim 2 \mathrm{~cm}^{2}$ leaf disc from the same leaf sample used for leaf anatomical and stomatal measurement, minor vein density (i.e., minor vein length per leaf area) was determined. After the epidermis was removed with a sharp razor blade, the remaining leaf samples were put in bleach (Clorox Professional Products Company, Oakland, CA, USA) to clear mesophyll cells. The samples were then stained with toluidine blue (Electron Microscopy Sciences, Hatfield, PA, USA) and imaged under microscope. The length minor vein per leaf area was measured with Image J manually.

\subsection{Biomass, $C$ and $N$ Content and Nutrient Composition Quantification}

All plants were harvest on 23 August (DOY 235) in 2018. Three individuals of each plot were selected for the biomass, $\mathrm{C}$ and $\mathrm{N}$ content measurement. Leaf area was measured by an area meter (LI-2000, LICOR Biosciences, Lincoln, NE, USA) and the number of tillers of each plant was counted. Leaf and stem dry mass were determined after oven-drying for 1 week at $50{ }^{\circ} \mathrm{C}$. Leaf dry mass per area (LMA) was calculated as dry mass/ area. Dried leaf and stem samples were then ground and weighted, and $\mathrm{C}$ and $\mathrm{N}$ content (\%) was determined by a Costech 4010 elemental analyzer (Costech Analytical Technologies, Inc., Valencia, CA, USA).

Macro- and micronutrients were quantified as previously described [98] by inductively high-resolution coupled plasma mass spectrometry (Element $2^{\mathrm{TM}}$, Thermo Scientific). Briefly, samples were submitted to a microwave acid sample digestion (Multiwave ECO, Anton Paar, les Ulis, France) ( $1 \mathrm{~mL}$ of concentrated $\mathrm{HNO}_{3}, 250 \mu \mathrm{L}$ of $\mathrm{H}_{2} \mathrm{O}_{2}$ and $900 \mu \mathrm{L}$ of Milli-Q water for $40 \mathrm{mg}$ DW). All samples 
were previously spiked with two internal standard solutions of gallium and rhodium for final concentrations of 10 and $2 \mu \mathrm{g} \mathrm{L}{ }^{-1}$. After acid digestion, samples were diluted to $50 \mathrm{~mL}$ with Milli-Q water to obtain solutions containing $2.0 \%(\mathrm{v} / \mathrm{v})$ of nitric acid, then filtered at $0.45 \mu \mathrm{m}$ using a teflon filtration system. Quantification of each element was performed using external standard calibration curves. The quality of mineralization and analysis were checked using a certified reference material of Citrus leaves (CRM NCS ZC73018, Sylab, Metz, France). Isotopic analysis of C and N was performed with a continuous flow isotope mass spectrometer (Isoprime, GV Instruments, Manchester, UK) linked to a $\mathrm{C} / \mathrm{N} / \mathrm{S}$ analyser (EA3000, EuroVector, Milan, Italy).

\subsection{Statistical Analysis}

The differences in physiological and structural traits between ambient and elevated $\mathrm{O}_{3}$ were tested with one-way ANOVA followed by the Tukey's post hoc test using SPSS 16.0 (SPSS, Chicago, Illinois, USA). The differences in slope and intercept of BMB relationship (observed stomatal conductance vs. $\frac{A H_{s}}{C_{S}}$ ) between ambient and elevated $\mathrm{O}_{3}$ were tested with standardized major axis tests using SMATR v2.0 [99]. All statistical tests were considered significant at $p<0.05$.

Author Contributions: E.A.A. designed the study; S.L., G.C. and A.O. performed the measurements; S.L. performed the statistical analysis; S.L., and E.A.A. contributed to the interpretation of results; and S.L. wrote the first version of the manuscript, which was reviewed and revised by all the authors

Acknowledgments: We would like to thank Jesse McGrath, Chris Moller, Noah Mitchell and Aidan McMahon for technical and field assistance. We also would like to thank Prof. DoKyoung Lee (University of Illinois at Urbana-Champaign) for providing plant materials. The authors acknowledge the PLATIN' (Plateau d'Isotopie de Normandie) core facility for the nutrient and isotope analysis used in this study. This work was funded by the DOE Center for Advanced Bioenergy and Bioproducts Innovation (U.S. Department of Energy, Office of Science, Office of Biological and Environmental Research under Award Number DE-SC0018420).

Conflicts of Interest: The authors declare no conflict of interest. Any opinions, findings, and conclusions or recommendations expressed in this publication are those of the author(s) and do not necessarily reflect the views of the U.S. Department of Energy.

\section{References}

1. McLaughlin, S.B.; De La Torre Ugarte, D.G.; Jr Garten, C.T.; Lynd, L.R.; Sanderson, M.A.; Tolbert, V.R.; Wolf, D.D. High-value renewable energy from prairie grasses. Environ. Sci. Technol. 2002, 36, 2122-2129. [CrossRef]

2. Tilman, D.; Socolow, R.; Foley, J.A.; Hill, J.; Larson, E.; Lynd, L.; Pacala, S.; Reilly, J.; Searchinger, T.; Somerville, C.; et al. Beneficial biofuels-the food, energy, and environment trilemma. Science 2009, 325, 270-271. [CrossRef] [PubMed]

3. Wullschleger, S.D.; Davis, E.B.; Borsuk, M.E.; Gunderson, C.A.; Lynd, L.R. Biomass production in switchgrass across the United States: Database description and determinants of yield. Agron. J. 2010, 102, 1158-1168. [CrossRef]

4. Vadas, P.A.; Barnett, K.H.; Undersander, D.J. Economics and energy of ethanol production from alfalfa, corn, and switchgrass in the upper Midwest, USA. Bioenerg. Res. 2008, 1, 44-55. [CrossRef]

5. U.S. Department of Energy. U.S. Billion-Ton Update: Biomass Supply for a Bioenergy and Bioproducts Industry. In ORNL/TM-2011/224; Perlack, R.D., Stokes, B.J., Eds.; Oak Ridge National Laboratory: Oak Ridge, TN, USA, 2011.

6. Moser, L.E.; Vogel, K.P. Switchgrass, big bluestem, and indiangrass. In An Introduction to Grassland Agriculture, 5th ed.; Barnes, R.F., Miller, D.A., Nelson, C.J., Eds.; Iowa State Univ. Press: Ames, IA, USA, 1995; pp. 409-420.

7. McLaughlin, S.B.; Kszos, L.A. Development of switchgrass (Panicum virgatum) as a bioenergy feedstock in the United States. Biomass Bioenergy 2005, 28, 515-535. [CrossRef]

8. Schmer, M.R.; Vogel, K.P.; Mitchell, R.B.; Perrin, R.K. Net energy of cellulosic ethanol from switchgrass. Proc. Natl. Acad. Sci. USA 2008, 105, 464-469. [CrossRef]

9. Vogel, K.P. Energy production from forages (or American agriculture-back to the future). J. Soil Water Conserv. 1996, 51, 137-139.

10. Casler, M.D.; Vogel, K.P.; Taliaferro, C.M.; Wynia, R.L. Latitudinal adaptation of switchgrass populations. Crop Sci. 2004, 44, 293-303. [CrossRef] 
11. Mitchell, R.; Vogel, K.P.; Sarath, G. Managing and enhancing switchgrass as a bioenergy feedstock. Biofuels Bioprod. Bioref. 2008, 2, 530-539. [CrossRef]

12. Stroup, J.A.; Sanderson, M.A.; Muir, J.P.; McFarland, M.J.; Reed, R.L. Comparison of growth and performance in upland and lowland switchgrass types to water and nitrogen stress. Bioresour. Technol. 2003, 86, 65-72. [CrossRef]

13. Barney, J.N.; Jeremiah Mann, J.; Kyser, G.B.; Blumwald, E.; Van Deynze, A.; DiTomaso, J.M. Tolerance of switchgrass to extreme soil moisture stress: Ecological implications. Plant Sci. 2009, 177, 724-732. [CrossRef]

14. Jiang, Y.; Yao, Y.; Wang, Y. Physiological response, cell wall components, and gene expression of switchgrass under short-term drought stress and recovery. Crop Sci. 2012, 52, 2718-2727. [CrossRef]

15. Kim, S.; Rayburn, A.L.; Voigt, T.; Parrish, A.; Lee, D.K. Salinity effects on germination and plant growth of prairie cordgrass and switchgrass. Bioenerg. Res. 2012, 5, 225-235. [CrossRef]

16. Sanderson, M.A.; Adler, P.R.; Boateng, A.A.; Casler, M.D.; Sarath, G. Switchgrass as a biofuels feedstoack in the USA. Can. J. Plant Sci. 2006, 86, 1315-1325. [CrossRef]

17. Sillman, $\mathrm{S}$. The relation between ozone, $\mathrm{NO}_{\mathrm{x}}$ and hydrocarbons in urban and polluted rural environments. Atmos. Environ. 1999, 33, 1821-1845. [CrossRef]

18. Atkinson, R. Atmospheric chemistry of VOCs and NOx. Atmos. Environ. 2000, 34, 2063-2101. [CrossRef]

19. Fowler, D.; Amann, M.; Anderson, F.; Ashmore, M.; Cox, P.; Depledge, M.; Derwent, D.; Grennfelt, P.; Hewitt, N.; Hov, O.; et al. Ground-Level Ozone in the 21st Century: Future Trends, Impacts and Policy Implications; The Royal Society: London, UK, 2008.

20. Sharma, P.; Kuniyal, J.C.; Chand, K.; Guleria, R.P.; Dhyani, P.P.; Chauhau, C. Surface ozone concentration and its behaviour with aerosols in the northwestern Himalaya, India. Atmos. Environ. 2013, 71, 44-53. [CrossRef]

21. Monks, P.S.; Archibald, A.T.; Colette, A.; Cooper, O.; Coyle, M.; Derwent, R.; Fowler, D.; Granier, C.; Law, K.S.; Mills, G.E.; et al. Tropospheric ozone and its precursors form the urban to the global scale from air quality to short-lived climate forcer. Atmos. Chem. Phys. 2015, 15, 8889-8973. [CrossRef]

22. Yuan, X.; Calatayud, V.; Jiang, L.; Manning, W.J.; Hayes, F.; Tian, Y.; Feng, Z. Assessing the effects of ambient ozone in China on snap bean genotypes by using ethylenediurea (EDU). Environ. Pollut. 2015, 205, 199-208. [CrossRef] [PubMed]

23. Ainsworth, E.A. Understanding and improving global crop response to ozone pollution. Plant J. 2017, 90, 886-897. [CrossRef] [PubMed]

24. Auvray, M.; Bey, I. Long-range transport to Europe: Seasonal variations and implications for the European ozone budget. J. Geophys. Res. 2005, 110, D11303. [CrossRef]

25. Liao, K.J.; Hou, X.; Baker, D.R. Impacts of interstate transport of pollutants on high ozone events over the Mid-Atlantic United States. Atmos. Environ. 2014, 84, 100-112. [CrossRef]

26. Weiss-Penzias, P.; Jaffe, D.A.; Jaegle', L.; Liang, Q. Influence of long-range-transported pollution on the annual and diurnal cycles of carbon monoxide and ozone at Cheeka Peak Observatory. J. Geophys. Res. 2004, 109, D23S14. [CrossRef]

27. Feng, Z.; Kobayashi, K.; Ainsworth, E.A. Impact of elevated ozone concentration on growth, physiology, and yield of wheat (Triticum aestivum L.): A meta-analysis. Glob. Chang. Biol. 2008, 14, 2696-2708.

28. Wittig, V.E.; Ainsworth, E.A.; Naidu, A.L.; Karnosky, D.F.; Long, S.P. Quantifying the impact of current and future tropospheric ozone on the tree biomass, growth, physiology and biochemistry: A quantitative meta-analysis. Glob. Chang. Biol. 2009, 15, 396-424. [CrossRef]

29. Ainsworth, E.A.; Yendrek, C.R.; Sitch, S.; Collins, W.J.; Emberson, L.D. The effects of tropospheric ozone on net primary productivity and implications for climate change. Annu. Rev. Plant. Biol. 2012, 63, 637-661. [CrossRef] [PubMed]

30. Wilkinson, S.; Mills, G.; Illidge, R.; Davies, W.J. How is ozone pollution reducing our food supply? J. Exp. Bot. 2012, 63, 527-536. [CrossRef] [PubMed]

31. McGrath, J.M.; Betzelberger, A.M.; Wang, S.; Shook, E.; Zhu, X.-G.; Long, S.P.; Ainsworth, E.A. An analysis of ozone damage to historical maize and soybean yields in the United States. Proc. Natl. Acad. Sci. USA 2015, 112, 14390-14395. [CrossRef] [PubMed]

32. Rebouças, D.M.; De Sousa, Y.M.; Bagard, M.; Costa, J.H.; Jolivet, Y.; De Melo, D.F.; Repellin, A. Combined effects of ozone and drought on the physiology and membrane lipids of two cowpea (Vigna unguiculata (L.) Walp) cultivars. Plants 2017, 6, 14. [CrossRef] [PubMed] 
33. Mills, G.; Sharps, K.; Simpson, D.; Pleijel, H.; Broberg, M.; Uddling, J.; Jaramillo, F.; Davies, W.; Dentener, F.; Van den Berg, M.; et al. Ozone pollution will compromise efforts to increase global wheat production. Glob. Chang. Biol. 2018, 24, 3560-3574. [CrossRef]

34. Ainsworth, E.A.; Lemonnier, P.; Wedow, J.M. The influence of rising tropospheric carbon dioxide and ozone on plant productivity. Plant Biol. 2019. [CrossRef]

35. Heath, R.L. The Biochemistry of Ozone Attack on the Plasma Membrane of Plant Cells. In Phytochemical Effects of Environmental Compounds. Recent Advances in Phytochemistry; Saunders, J.A., Kosak-Channing, L., Conn, E.E., Eds.; Springer: Boston, MA, 1987; Volume 21.

36. Long, S.P.; Naidu, S.L. Effect of oxidants at the biochemical, cell and physiological levels, with particular reference to ozone. In Air Pollution and Plant Life; Bell, J.N.B., Treshow, M., Eds.; John Wiley \& Sons, Ltd.: West Sussex, UK, 2002; pp. 69-88.

37. Pasqualini, S.; Piccioni, C.; Reale, L.; Ederli, L.; Della, T.G.; Ferranti, F. Ozone-induced cell death in tobacco cultivar Bel W3 plant. The role of programmed cell death in lesion formation. Plant Physiol. 2003, 133, 1122-1134. [CrossRef]

38. Fiscus, E.L.; Booker, F.L.; Burkey, K.O. Crop responses to ozone: Uptake, models of action, carbon assimilation and partitioning. Plant Cell Environ. 2005, 28, 997-1011. [CrossRef]

39. Li, S.; Harley, P.C.; Niinemets, Ü. Ozone-induced foliar damage and release of stress volatiles is highly dependent on stomatal openness and priming by low-level ozone exposure in Phaseolus vulgaris. Plant Cell Environ. 2017, 40, 1984-2003. [CrossRef]

40. Flowers, M.D.; Fiscus, E.L.; Burkey, K.O.; Booker, F.L.; Dubois, J.-J.B. Photosynthesis, chlorophyll fluorescence, and yield of snap bean (Phaseolus vulgaris L.) genotypes differing in sensitivity to ozone. Environ. Exp. Bot. 2007, 61, 190-198. [CrossRef]

41. Guidi, L.; Degl'Innocenti, E.; Martinelli, F.; Piras, M. Ozone effects on carbon metabolism in sensitive and insensitive Phaseolus cultivars. Environ. Exp. Bot. 2009, 66, 117-125. [CrossRef]

42. Li, S.; Tosens, T.; Harley, P.C.; Jiang, Y.; Kanagendran, A.; Grosberg, M.; Jaamets, K.; Niinemets, Ü. Glandular trichomes as a barrier against atmospheric oxidative stress: Relationships with ozone uptake, leaf damage, and emission of LOX products across a diverse set of species. Plant Cell Environ. 2018, 40, 1263-1277. [CrossRef]

43. Masutomi, Y.; Kinose, Y.; Takimoto, T.; Yonekura, T.; Oue, H.; Kobayashi, K. Ozone changes the linear relationship between photosynthesis and stomatal conductance and decreases water use efficiency in rice. Sci. Total Environ. 2019, 655, 1009-1016. [CrossRef]

44. Paoletti, E.; Grulke, N.E. Does living in elevated $\mathrm{CO}_{2}$ ameliorate tree response to ozone? A review on stomatal responses. Environ. Pollut. 2005, 137, 483-493. [CrossRef]

45. Vahisalu, T.; Puzõrjova, I.; Brosché, M.; Valk, E.; Lepiku, M.; Moldau, H.; Pechter, P.; Wang, Y.-S.; Lindgren, O.; Salojärvi, J.; et al. Ozone-triggered rapid stomatal response involves the production of reactive oxygen species, and is controlled by SLAC1 and OST1. Plant J. 2010, 62, 442-453. [CrossRef]

46. Paoletti, E.; Grulke, N.E. Ozone exposure and stomatal sluggishness in different plant physiognomic classes. Environ. Pollut. 2010, 158, 2664-2671. [CrossRef]

47. Hoshika, Y.; Omasa, K.; Paoletti, E. Both ozone exposure and soil water stress are able to induce stomatal sluggishness. Environ. Exp. Bot. 2013, 88, 19-23. [CrossRef]

48. Ball, J.T.; Woodrow, I.E.; Berry, J.A. A model predicting stomatal conductance and its contribution to the control of photosynthesis under different environmental conditions. In Progress in Photosynthesis Research; Biggins, J., Ed.; Martinus Nijhoff Publishers: Dordrecht, The Netherlands, 1987; pp. 221-224.

49. Wolz, K.J.; Wertin, T.M.; Abordo, M.; Wang, D.; Leakey, A.D.B. Diversity in stomatal function is integral to modelling plant carbon and water fluxes. Nat. Ecol. Evol. 2017, 1, 1292-1298. [CrossRef]

50. Leitao, L.; Bethenod, O.; Biolley, J.-P. The impact of ozone on juvenile maize (Zea mays L.) plant photosynthesis: Effects on vegetative biomass, pigmentation, and carboxylases (PEPc and rubisco). Plant Biol. 2007, 9, 478-488. [CrossRef]

51. Leitao, L.; Maoret, J.J.; Biolley, J.P. Changes in PEP carboxylase, rubisco and rubisco activase mRNA levels from maize (Zea mays) exposed to a chronic ozone stress. Biol. Res. 2007, 40, 137-153. [CrossRef]

52. Singh, A.A.; Agrawal, S.B.; Shahi, J.P.; Agrawal, M. Assessment of growth and yield losses in two Zea mays L. cultivars (quality protein maize and nonquality protein maize) under projected levels of ozone. Environ. Sci. Pollut. Res. 2014, 21, 2628-2641. [CrossRef] 
53. Yendrek, C.R.; Erice, G.; Montes, C.M.; Tomaz, T.; Sorgini, C.A.; Brown, P.J.; McIntyre, L.M.; Leakey, A.D.B.; Ainsworth, E.A. Elevated ozone reduces photosynthetic carbon gain by accelerating leaf senescence of inbred and hybrid maize in a genotype-specific manner. Plant Cell Environ. 2017, 40, 3088-3100. [CrossRef]

54. Yendrek, C.R.; Tomaz, T.; Montes, C.M.; Cao, Y.; Morse, A.M.; Brown, P.J.; McIntyre, L.M.; Leakey, A.D.B.; Ainsworth, E.A. High-throughput phenotyping of maize leaf physiological and biochemical traits using hyperspectral reflectance. Plant Physiol. 2017, 173, 614-626. [CrossRef]

55. Grantz, D.A.; Vu, H.B. $\mathrm{O}_{3}$ sensitivity in a potential $\mathrm{C}_{4}$ bioenergy crop: Sugarcane in California. Crop Sci. 2009, 49, 643-650. [CrossRef]

56. Grantz, D.A.; Vu, H.B.; Tew, T.L.; Veremis, J.C. Sensitivity of gas exchange parameters to ozone in diverse $\mathrm{C}_{4}$ sugarcane hybrids. Crop Sci. 2012, 52, 1270-1280. [CrossRef]

57. Moura, B.B.; Hoshika, Y.; Ribeiro, R.V.; Paoletti, E. Exposure- and flux-based assessment of ozone risk to sugarcane plants. Atmos. Environ. 2018, 176, 252-260. [CrossRef]

58. Bussotti, F. Functional leaf traits, plant communities and acclimationprocesses in relation to oxidative stress in trees: A critical overview. Glob. Chang. Biol. 2008, 14, 2727-2739.

59. Grass Phylogeny Working Group. Phylogeny and subfamilial classification of the grasses (Poaceae). Ann. Mo. Bot. Gard. 2001, 88, 373-457. [CrossRef]

60. Reich, P.B. Quantifying plant response to ozone: A unifying theory. Tree Physiol. 1987, 3, 63-91. [CrossRef]

61. Hoshika, Y.; Katata, G.; Deushi, M.; Watanabe, M.; Koike, T.; Paoletti, E. Ozone-induced stomatal sluggishness changes carbon and water balance of temperate deciduous forests. Sci. Rep. 2015, 5, 09871. [CrossRef]

62. Li, P.; Calatayud, V.; Gao, F.; Uddling, J.; Feng, Z. Differences in ozone sensitivity among woody species are related to leaf morphology and antioxidant levels. Tree Physiol. 2016, 36, 1105-1116. [CrossRef]

63. Feng, Z.; Büker, P.; Pleijel, H.; Emberson, L.; Karlsson, P.E.; Uddling, J. A unifying explanation for variation in ozone sensitivity among woody plants. Glob. Chang. Biol. 2018, 24, 78-84. [CrossRef]

64. Pignon, C.P.; Lundgren, M.R.; Osborne, C.P.; Long, S.P. Bundle sheath chloroplast volume can house sufficient Rubisco to avoid limiting C4 photosynthesis during chilling. J. Exp. Bot. 2019, 70, 357-365. [CrossRef]

65. Zhang, W.-W.; Wang, M.; Wang, A.-Y.; Yin, X.-H.; Feng, Z.-Z.; Hao, G.-Y. Elevated ozone concentration decreases whole-plant hydraulic conductance and disturbs water use regulation in soybean plants. Physiol. Plant. 2018, 163, 183-195. [CrossRef]

66. Hu, J.; Yang, Q.-Y.; Huang, W.; Zhang, S.B.; Hu, H. Effects of temperature on leaf hydraulic architecture of tobacco plants. Planta 2014, 240, 489-496. [CrossRef] [PubMed]

67. Uhl, D.; Mosbrugger, V. Leaf venation density as a climate and environmental proxy: A critical review and new data. Palaeogeogr. Palaeoclimatol. Palaeoecol. 1999, 149, 15-26. [CrossRef]

68. Kouwenberg, L.L.; Kürschner, W.M.; McElwain, J.C. Stomatal frequency change over altitudinal gradients: Prospects for paleoaltimetry. Rev. Mineral. Geochem. 2007, 66, 215-241. [CrossRef]

69. Carins Murphy, M.R.; Jordan, G.J.; Brodribb, T.J. Acclimation to humidity modifies the link between leaf size and the density of veins and stomata. Plant Cell Environ. 2014, 37, 124-131. [CrossRef]

70. Brodribb, T.J.; Jordan, G.J.; Carpenter, R.J. Unified changes in cell size permit coordinated lead evolution. New Phytol. 2013, 199, 559-570. [CrossRef]

71. Leisner, C.P.; Ainsworth, E.A. Quantifying the effects of ozone on plant reproductive growth and development. Glob. Chang. Biol. 2012, 18, 606-616. [CrossRef]

72. Yendrek, C.R.; Leisner, C.P.; Ainsworth, E.A. Chronic ozone exacerbates the reduction in photosynthesis and acceleration of senescence caused by limited N availability in Nicotiana sylvestris. Glob. Chang. Biol. 2013, 19, 3155-3166. [CrossRef] [PubMed]

73. Longstreth, D.J.; Nobel, P.S. Nutrient influences on leaf photosynthesis. Plant Physiol. 1980, 65, 541-543. [CrossRef] [PubMed]

74. Spiller, S.; Terry, N. Limiting factors in photosynthesis: II. iron stress diminishes photochemical capacity by reducing the number of photosynthetic units. Plant Physiol. 1980, 65, 121-125. [CrossRef] [PubMed]

75. Zhao, D.; Oosterhuis, D.M.; Bednarz, C.W. Influence of potassium deficiency on photosynthesis, chlorophyll content, and chloroplast ultrastructure of cotton plants. Photosynthetica 2001, 39, 103-109. [CrossRef]

76. Lewandowski, I.; Kicherer, A. Combustion quality of biomass: Practical relevance and experiments to modify the biomass quality of Miscanthus $\times$ giganteus. Eur. J. Agron. 1997, 6, 163-177. [CrossRef]

77. Reich, P.B.; Schoettle, A.W. Effects of ozone and acid rain on white pine (Pinus strobus) seedlings grown in five soils. III Nutrient relations. Can. J. Bot. 1988, 66, 1517-1531. [CrossRef] 
78. Oksanen, E.; Riikonen, J.; Kaakinen, S.; Holopainen, T.; Vapaavuori, E. Structural characteristics and chemical composition of birch (Betula pendula) leaves are modified by increasing $\mathrm{CO}_{2}$ and ozone. Glob. Chang. Biol. 2005, 11, 732-748. [CrossRef]

79. Thomas, V.F.D.; Braun, S.; Flückiger, W. Effects of simultaneous ozone exposure and nitrogen loads on carbohydrate concentrations, biomass, growth, and nutrient concentrations of young beech trees (Fagus sylvatica). Environ. Pollut. 2006, 143, 341-354. [CrossRef] [PubMed]

80. Farquhar, G.D.; O'Leary, M.H.; Berry, J.A. On the relationship between carbon isotope discrimination and the intercellular carbon dioxide concentration in leaves. Aust. J. Plant Physiol. 1982, 9, 121-137. [CrossRef]

81. Farquhar, G.D.; Ehleringer, J.R.; Hubick, K.T. Carbon isotope discrimination and photosynthesis. Annu. Rev. Plant Physiol. Plant Mol. Biol. 1989, 40, 503-537. [CrossRef]

82. Farquhar, G.D.; Richards, R.A. Isotopic composition of plant carbon correlates with water-use efficiency of wheat genotypes. Aust. J. Plant Physiol. 1984, 11, 539-552. [CrossRef]

83. Handley, L.L.; Raven, J.A. The use of natural abundance of nitrogen isotopes in plant physiology and ecology. Plant Cell Environ. 1992, 15, 965-985. [CrossRef]

84. Evans, R.D. Physiological mechanisms influencing plant nitrogen isotope composition. Trends Plant Sci. 2001, 6, 121-126. [CrossRef]

85. Robinson, D. $\delta^{15} \mathrm{~N}$ as an integrator of the nitrogen cycle. Trends Ecol. Evol. 2001, 16, 153-162. [CrossRef]

86. Morgan, P.B.; Bernacchi, C.J.; Ort, D.R.; Long, S.P. An in vivo analysis of the effect of season-long open-air elevation of ozone to anticipated 2050 levels on photosynthesis in soybean. Plant Physiol. 2004, 135, 2348-2357. [CrossRef]

87. Naidu, S.L.; Long, S.P. Potential mechanisms of low-temperature tolerance of $\mathrm{C}_{4}$ photosynthesis in Miscanthus $\times$ giganteus: An in vivo analysis. Planta 2004, 220, 145-155. [CrossRef]

88. Leakey, A.D.B.; Uribelarrea, M.; Ainsworth, E.A.; Naidu, S.L.; Rogers, A.; Ort, D.R.; Long, S.P. Photosynthesis, productivity, and yield of maize are not affected by open-air elevation of $\mathrm{CO}_{2}$ concentration in the absence of drought. Plant Physiol. 2006, 140, 779-790. [CrossRef]

89. Nardini, A.; Gortan, E.; Ramani, M.; Salleo, S. Heterogeneity of gas exchange rates over the leaf surface in tobacco: An effect of hydraulic architecture? Plant Cell Environ. 2008, 31, 804-812. [CrossRef] [PubMed]

90. Li, S.; Zhang, Y.J.; Sack, L.; Scoffoni, C.; Ishida, A.; Chen, Y.-J.; Cao, K.-F. Heterogeneity and spatial pattering of structure and physiology across the leaf surface in giant leaves of Alocasia macrorrhiza. PLoS ONE 2013, 8, e66016.

91. Bernacchi, C.J.; Morgan, P.B.; Ort, D.R.; Long, S.P. The growth of soybean under free air [CO2] enrichment (FACE) stimulates photosynthesis while decreasing in vivo Rubisco capacity. Planta 2005, 220, 434-446. [CrossRef] [PubMed]

92. Farquhar, G.D.; von Caemmere, S.; Berry, J.A. A biochemical model of photosynthetic $\mathrm{CO}_{2}$ fixation in $\mathrm{C}_{3}$ species. Planta 1980, 149, 178-190. [CrossRef]

93. Von Caemmerer, S. Biochemcial models of leaf photosynthesis; CSIRO Publishing: Collingwood, Australia, 2000.

94. Markelz, R.J.C.; Strellner, R.S.; Leakey, A.D.B. Impairment of $\mathrm{C}_{4}$ photosynthesis by drought is exacerbated by limiting nitrogen and ameliorated by elevated $\left[\mathrm{CO}_{2}\right]$ in maize. J. Exp. Bot. 2011, 62, 3235-3246. [CrossRef]

95. Twidwell, E.K.; Johnson, K.D.; Patterson, J.A.; Cherney, J.H.; Bracker, C.E. Degradation of switchgrass anatomical tissue by rumen microorganisms. Crop Sci. 1991, 30, 1321-1328. [CrossRef]

96. Christin, P.-A.; Osborne, C.P.; Chatelet, D.S.; Columbus, J.T.; Besnard, G.; Hodkinson, T.R.; Garrison, L.M.; Vorontsove, M.S.; Edwards, E.J. Anatomical enablers and the evolution of C4 photosynthesis in grasses. Proc. Natl. Acad. Sci. USA 2013, 110, 1381-1386. [CrossRef]

97. Sack, L.; Cowan, P.D.; Jaikumar, N.; Holbrook, N.M. The hydrology of leaves: Co-ordination of structure and function in temperate woody species. Plant Cell Environ. 2003, 26, 1343-1356. [CrossRef]

98. Maillard, A.; Etienne, P.; Diquélou, S.; Trouverie, J.; Billard, V.; Yvin, J.C.; Ourry, A. Nutrient deficiencies modify the ionomic composition of plant tissues: A focus on cross-talk between molybdenum and other nutrients in Brassica napus. J. Exp. Bot. 2016, 67, 5631-5641. [CrossRef] [PubMed]

99. Warton, D.I.; Wright, I.J.; Falster, D.S.; Westoby, M. Bivariate line-fitting methods for allometry. Biol. Rev. 2006, 81, 259-291. [CrossRef] [PubMed]

(C) 2019 by the authors. Licensee MDPI, Basel, Switzerland. This article is an open access article distributed under the terms and conditions of the Creative Commons Attribution (CC BY) license (http://creativecommons.org/licenses/by/4.0/). 